\title{
PENDIDIKAN ISLAM DI eRA MILENIAL
}

\author{
Abuddin Nata \\ (Guru Besar Ilmu Pendidikan Islam Fakultas Ilmu Tarbiyah \\ dan Keguruan Universitas Islam Negeri (UIN) Syarif Hidayatullah Jakarta)
}

\begin{abstract}
Today humans live in the millennial era. The era that is a continuation of this global era has created new challenges that must be transformed into opportunities that can be put to good use, so that challenge brings a blessing for everyone to do. Since the millennial era besides having similarities also has differences, especially in the use of digital technology that goes beyond the computer era, this kaeadaan has invited a number of experts to speak out and at the same time offer a number of thoughts and ideas in dealing with it. Islamic education with various types and levels, ranging from traditional pesantren that is non-formal, hinggapesantren modern with various programs, ranging from kindergarten to college, is institutionally part of the national education system. With such a position, Islamic education will inevitably have to contribute, even responsible menak prepare human beings in the millennial era. That is a human being who is able to change challenges into opportunities, and can use them for his own material and spiritual welfare. This paper seeks to explore the potential contained in Islamic education with various types and levels in the face of challenges in the millennial era. This paper begins by presenting the characteristics and challenges of the millennial era, social problems and their impact on life.
\end{abstract}

Keywords: Islamic Education, Millennial Era, Challenges and Opportunities.

\footnotetext{
Abstrak

Dewasa ini manusia hidup di era millennial. Era yang merupakan kelanjutan dari era global ini telah menimbulkan tantangan-tantangan baru yang harus diubah menjadi peluang yang dapat dimanfaatkan dengan sebaik-baiknya, sehingga tantangan tersebut membawa berkah bagi setiap orang melakukannya. Karena era millennial selain memiliki persamaan juga memiliki perbedaan, terutama dalam penggunaan digital technology yang melampaui era computer, maka kaeadaan ini telah mengundang sejumlap pakar untuk angkat bicara dan sekaligus menawarkan sejumlah pemikiran dan gagasan dalam menghadapinya. Pendidikan Islamdengan beragam jenis dan jenjangnya, mulai
}

dari pesantren tradisional yang bersifat non-formal, hinggapesantren modern dengan berbagai programnya, mulai dari Taman Kanak-kanak hingga perguruan tinggi, secara institusional merupakan bagian dari sistem pendidikan nasional. Dengan posisinya yang demikian itu, pendidikan Islam mau tidak mau harus ikut berkontribusi, bahkan bertanggung jawabdakam menyiapkan manusia dalam menghadapi era millennial. Yaitu manusia yang mampu merubah tantang menjadi peluang, serta dapat memanfaatkannya guna kesejahteraan hidunya secara material dan spiritual. Tulisan ini berupaya menggali potensi yang terdapat dalam pendidikan Islam dengan berbagai jenis dan jenjangnya dalam menghadapi tantangan di era millennial. Tulisan ini diawali dengan mengemukakan karakteristik dan tantangan era millennial, problema sosial dan dampaknya bagi kehidupan.

Katakunci: Pendidikan Islam, Era Millennial, Tantangan Dan Peluang.

\section{Karakteristik dan Tantangan Era Millenial}

Kosakata millennial berasal dari bahasa Inggris millennium atau millennia yang berarti masa seribu rahun (Echols, 1980: 380). Millennia selanjutnya menjadi sebutan untuk sebuah masa yang terjadi setelah era global, atau era modern. Karena itu, era millennial dapat pula disebut erapost-modern. Era ini oleh sebagian pakar diartikan sebagai era back to spiritual and moral atau back to religion. Yaitu masa kembali kepada ajaran spiritual, moraldan agama. Era ini muncul sebagai respon terhadap era modern yang lebih mengutamakan akal, empirik, danhal-hal yang bersifat materialistik, sekularistik, hedonistik, fragmatik, dan transaksional. Yaitu pandangan yang memisahkan urusan dunia dengan urusan akhirat. Akibat dari kehidupan yang demikian itu manusia menjadi bebas berbuat tanpa landasan spiritual, moral, dan agama. Kehidupan yang demikian, memang telah mengantarkan manusiakepada tahap membuat sesuatu yang mengagumkan, seperti digital technology, cloning, dan sebagainya. Namun karena tidak disertai landasan spiritual, moral dan agama, semua temuan yang mengagumkan itu telah pula digunakan manusia untuk mendukung selera hawa nafsunya. Praktik 
ekonomi yang kapitalistik dan berjiwa predator, politik yang menghalalkan segala cara, peredaran Narkoba, perdagangan manusia, korupsi, hingga praktek LGBT (Lesbian, gay, be seksual, gay dan trangender), perusakan lingkungan dan sebagainya, nampak semakin canggih, karena didukung oleh digital technology yang dilakukan oleh manusia generasi millennialis.

Kehidupan yang demikian didasarkan pada assumsi, bahwa dengan akal, panca indera, dan materi yang didukung oleh ilmu pengetahuan dan teknologi canggih semua masalah dapat dipecahkan. Ingin bepergian jauh tinggal pesan tiket pesawat; ingin tidur nyenyak dan makan nikmat tinggal pergi ke hotel dan restoran, ingin senang-senang, tinggal pergi ke tempat hiburan; ingin sehat tinggal panggil dokter, dan ingin pandai tinggal panggil guru atau nara sumber; ingin memperoleh informasi tingggal lihat Google. Demikian seterusnya. Sementara itu agama dipandang tidak perlu ikut campur, karena akan menghambat kebebasan manusia dalam mencapai kemajuannya.

Namun demikian, assumsi bahwa semua masalah dapat dipecahkan dengan bantuan panca indera, akal, ilmu pengetahuan dan teknologi, ternyata meleset. Panca indera, akal, Ilmu pengetahuan dan teknologicanggih tidak dapat menyelesaikan masalah yang amat krusial dan luas sebagaimana telah disebutkan di atas. Panca indera, akal, ilmu pengetahuan dan teknologi canggih, ternyata bukanlah tujuan, melainkan hanya alat. Semua itu memangdapat membawa kemajuan dan menjawab kebutuhan manusia, namun tidak semuanya, hanya mengatasi akibat dan bukan sebab atau penyebabnya. Masalah moral, seperti korupsi, perkosaan, dan penipuan, masalahspiritual seperti tidak tidak merasa berdosa kalau berbuat maksiat dan kesalahan, dan selalu merasa tidak puas;masalah sosial seperti konflik yang dipicu isu SARA, bahkan penjajahan dan peperangan, tidak dapat diatasi oleh ilmu dan teknologi canggih semata. Pemecahan masalah tersebut membutuhkanagama, moral danspiritual.

Selain itu, diketahui, bahwa manusia, sebagai makhluk yang memiliki fithrah beragama yang dibawa sejak lahir, yakni rasa percaya kepada Tuhan, patuh dan tunduk kepada-Nya membutuhkan agama. Tanpa agama, manusia akan berada dalam kekosongan yang dapat berbahaya, karena dapat diisi dengan hal-hal yang buruk. Menjauhkan manusia dari agama, adalah suatu hal yang mustahil, karena bertentangan dengan fithrah manusia yang diberikan Tuhan (Q.S. al-Ruum, 30:30). Menganggap agama sudah mati juga suatu hal yang mutahil. Atas dasar ini, Komaruddin Hidayat menulis bukuAgama memiliki Seribu Nyawa.Buku tersebut menggambarkan adanya sejumlah orang yang berusaha membunuh agama, namun ternyata tidak berhasil; agama tetap hidup, butuh penyaluran dan asupan. Yakni ketika agama dibunuh, ternyata ia hidup lagi. Karena agama menyatu dalam fithrah manusia. Inilah di antara ciri jiwa manusia pada era post modern.

Era millennial sebagaimana yang terjadi saat ini selain memiliki ciri-ciri era post modern sebagaimana tersebut di atas, juga masih memiliki ciri-ciri era globalisasi yang antara lain adanya persaingan yang ketat sebagai akibat dari pasar bebas (free market); tuntutan untuk memperoleh perlakuan yang lebih adil, egaliter, manusiawi,dan demokratis, sebagai akibat dari fragmentasi politik; hegemoni politik sebagai akibat dari adanya kesaling tergantungan (interdependensi); harus belajar kembali sebagai akibat dari kemajuan ilmu pengetahuan dan teknologi; serta adanya kemerosotan moral (moral decadency) sebagai akibat dari masuknya budaya baru yang tidak sejalan dengan nilai-nilai ajaran agama (Bell, 2001, 27-33).

Dengan demikian ketika memasuki era millennial sesungguhnya ciri-ciri post modern dan ciri-globalisasi sebagaimana tersebut di atas, masih melekat. Hal tersebut akan terasa berat jika berbagai tantangan dan permasalahan yang terdapat pada setiap zaman tersebut belum dapat dipecahkan, sehingga masalah dan tantangannya bertumpuktumpuk. Semua itu akan terasa ringan, jika masalah dan tantangan yang terdapat pada post modern dan globalisasi sebagaimana tersebut di atas sudah dapat diatasi, sehingga tidak terlalu berat. Kesiapan manusia dalam menghadapi persamalahan tersebut kondisinya berbeda-beda. Yakni ada yang kondisinya masih berat, yakni ketika ia belum dapat memecahkan masalah post modern dan globalisasi, sudah datang lagi masalah baru; ada yang yang sudah ringan, yakni sudah dapat menyelesaikan masalah post modern dan era globalisasi, dan tinggalmenghadapi masalah era millennial. Selain itu ada pula kondisi manusia yang masih agak berat, yakni baru dapat menyelesaikan sebagian saja dari tantangan pada semua era tersebut.Pendidikan Islam sebagaimana dijelaskan di bagian bawah berikutnya tulisan akan menawarkan solusinya yang tepat.

Selanjutnya terkait dengan permasalahan dan tantangan yang terjadi di era millennial antara lain terkait dengan adanya sikap dan perilaku manusia yang ciri-cirinya antara lain: (1) suka dengan kebebasan; (2) senang melakukan personalisasi; (3) mengandalkan kecepatan informasi yang instant (siap saji); (4) suka belajar; (5)bekerja dengan lingkungan inovatif, (6) aktif berkolaborasi, dan (7) hyper technology (Tapscott, 2008) (8) critivcal, yakni terbiasa berfikir out of the box, kaya ide dan gagasan; (9) confidence, yakni mereka sangat percaya diri dan berani mengungkapkan pendapat tanpa ragu-ragu; (10) connected, yakni merupakan generasi yang pandai bersosialisasi, terutama dalam komunitas yang mereka ikuti; (11) berselancar di sosial media dan internet (Farouk, 2017, 7). (12) 
sebagai akibat dari ketergantungan yang tinggi terhadap internet dan media sosial, mereka menjadi pribadi yang malas, tidak mendalam, tidak membumi, atau tidak bersosialisasi; (13)cenderung lemah dalam nilai-nilai kebersamaan, kegotongroyongan, kehangatan lingkungan dan kepedulian sosial; (14)cenderung bebas, kebarat-baratan dan tidak memperhatikan etik dan aturan formal, adat istiadat, serta tata krama.

Dari empat belas sikap yang ditimbulkan di era millennialitu, nampaknya hanya butir 12, 13 dan 14 yang menyangkut dengan etos kerja, etika dan moral, yakni malas, tidak mendalam, tidak membumi, kurang peduli pada lingkungan, cenderung bebas, kebarat-baratan, dan melanggar etika. Semua masalah etika dan moral inilah yang menjadi tanggung jawab pendidikan Islam. Itulah sebabnya Noory Ajthariza mengatakan:

Dalam kaitannya dengan toleransi, satusatunya penjelasan adalah pendidikan. Semakin tinggi tingkat pendidikan seseorang, kecenderungan dia untuk bersikap terbuka dan toleran akan semakin tinggi. Pendidikan yang baik membuat seseorang makin bisa memilah dan mencerna informasi secara akurat di tengah-tengah timbunan informasi pasa era digital (Akhthariza, 2018, 7).

Era millineal dengan ciri-cirinya sebagaimana tersebut di atas pada ujungnya harus dihadapi dan dijawab oleh dunia pendidikan. Dalam hubungan ini, Mansur Fakih dalam tulisannya yang berjudul Ideologi dalam Pendidikan mengatakan:

Para praktisi pendidikan seperti para guru ataupun doses di Lembaga pendidikan ataupun sekolah formal, pelatih (trainer) pada tempat kursus maupun loka karya atau bahkan para pemandu pelatihan (fasilitator) di berbagai arena pendidikan non formal ataupun pendidikan rakyat (popular education) di kalangan buruh, petani ataupun rakyat miskin, banyak yang tidak sadar bahwa ia tengah terlibat dalam suatu pergumulan politik dan ideologi melalui arena pendidikan (Naomi, 2008, 10).

\section{Periodesasi Kehidupan}

Selanjutnya sebelum membahas peran pendidikan dalam mengatasi era millennial perlu pula dibicarakan periode atau tahapan kehidupan manusia, sehingga akan memudahkan dalam mengenali karakteristik serta permasalahan yang dihadapinya serta pemecahannya oleh pendidikan.

Para ahli sejarah umumnya membagi kehidupan dalam berbagai teori tentang periode. August Comte misalnya membagi kehidupan manusia berdasarkan kemampuan berfikir dan kebudayaan. Untuk itu ia membagi manusia ke dalam tahap teologis, metafisik, dan positifistik (Nanang,
2011: 34). Tahap teologis merupakan periode paling lama dalam sejarah manusia. Pada tahap ini manusia dan semua fenomena diciptakan oleh zat adikodrati, ditandai dengan kepercayaan manusia pada jimat. Periode ini dibagi dalam tiga subperiode, yaitu (1) fetisisme, yaitu bentuk pikiran yang dominan dalam masyarakat primitive, meliputi kepercayaan bahwa semua benda memiliki kelengkapan kekuatan hidupnya sendiri; pada tahap ini, manusia mulai mempercayai kekuatan jimat; (2) politheisme, yaitu muncul anggapan bahwa ada kekuatan-kekuatan yang mengatur kehidupan atau gejala alam. Pada tahap ini sudah mulai muncul kehidupan kota, pemilikan tanah menjadi institusi sosial, muncul sistem kasta, dan perang dianggap sebagai satusatunya cara untuk menciptakan kehidupan politik yang kekal; (3) monotheisme, yaitu kepercayaan bahwa peran dewa sudah digantikan dengan yang tunggal, dan puncaknya ditujukan pada Katolisisme. Selanjutnya tahap metafisika merupakan tahap transisi antara tahap teologis ke tahap positivistis. Tahap ini ditandai oleh suatu kepercayaan terhadaphukum alam yang asasi yang dapat ditemukan dalam akal budi. Pada tahap ini, manusia mengaggap bahwa pikiran bukanlah ciptaan zat adikodrati, namun merupakann ciptaan "kekuatan abstrak", sesuatu yag benar-benar dianggap ada, dan melekat dalam diri seluruh manusia dan mampu menciptakan semua fenomena. Selanjutnya pada tahap positivistis, manusia tidak lagi mencari penyebab fenomena, akan tetapi pikiran manusia mulai mencari hukum-hukum yang menentukan fenomena, yaitu menemukan rangkaian hubungan yang tidak berubah dan memiliki kesamaan. Tahap ini ditandai oleh adanya kepercayaan terhadap data empiris sebagai sumber pengetahuan terakhir, tetapi sekali lagi pengetahuan itu sifatnya sementara dan tidak mutlak. Analisis rasional mengenai data empiris akhirnya akan memungkinkan manusia untuk memperoleh hukum-hukum yang bersifat uniformitas (Nanang, 2011: 34-35).

Sementara itu, M. Amin Abdullah dengan mengambil inspirasi dari Keith Ward membagi kehidupan manusia ke dalam empat fase atau tahapan. Yaitu tahapanlocal (prehistorical periode), fase canonical atau propositional, fase critical dan faseglobal (M.Amin, 2009: 261-273). Pada tahap local (prehistorical periode) semua agama dapat dikategorikan sebagai lokal. Semua praktik tradisi, kultur, ada istiadat, norma, bahkan agama adalah fenomena lokal. Kelokalan ini tidak bisa dihindari sama sekali karena salah satu faktor utamanya adalah bahasa yang bersifat lokal dan merupakan warisan dari bangsa sebelumnya. Warisan lama prasejarah ini ternyata masih berlangsung sampai sekarang. Bahasa China, misalnya hanya terbatas pada dataran China. Begitu juga bahasa Jepang, Inggris, Arab, Melayu. Di Eropa sendiri ada beberapa bahasa, seperti Perancis, Jerman, Itali, Spanyol, Belanda, dan Inggris. Semua 
bahasa tersebuttidak ada yang sepenuhnya bersifat universal.

Selanjutnya pada fase canonical atau propositional, sebagai era agama-agama besar. Kehadiran agama-agama Ibrahim (Abrahamic Religion) (Graham E, 2010: 21), dan juga agamaagama di Timur, yang pada umunya menggunakan panduan Kitab Suci (The Sacred Text) merupakan babak baru tahapan sejarah perkembangan agamaagama dunia pasca prehistoric religions di atas. Budaya baca tulis (literacy) dengan menggunakan huruf sudah mulai dikenal dalam kehidupan umat manusia. Tradisi yang dahulunya "oral" (lisan) berubah menjadi "written" (tulis) dengan menggunakan alfabet, huruf, kata, anak kalimat, kalimat, dan begitu seterusnya. Masing-masing agama, baik Abrahamic religion (Yahudi, Kristen, Islam), maupun Eastern religion (agama-agama Timur) mempunyai kitab suci sebagai panduan hidup moral, hukum dan sosial.

Dalam pada itu, fase critical yang dimulai abad ke-16 dan 17, ditandai antara lain oleh adanya kesadaran beragama di Eropa yang mengalami perubahan yang radikal, dan terwadahi dalam gerakan Enlighttenment. Meskipun ini adalah pengalaman Eropa, tetapi dalam perkembangannya juga merambah ke seluruh tradisi agama-agama dunia selain Kristiani dan Yahudi Eropa. Agamaagama tradisional menghadapi tantangan berat sehingga memaksa para penganutnya untuk memikirkan kembali secara menyeluruh asumsiasumsi dasar yang telah menjadi habit of mind dan belief. Dua tantangan besar tersebut adalah prinsipprinsip berfikir yang harus berdasarkan pada buktibukti riil di lapangan (the principle of evidentalism) dalam arti bahwa seluruh kepercayaan hendaknya secara proporsional bersedia (legowo) untuk menghadapi pertanyaan dan pertanggungjawaban uji public-serta prinsip otonomi moral (the principle of autonomy) dalam arti bahwasanya kepercayaan agama, khususnya hal-hal yang terkait dengan persoalan moral (moral beliefs) hendaknya tidak berdasarkan atas otoritas.Kalau umat beragama menerima kedua prinsip Enlighttenment ini, maka kepercayaan agama dalam bentuknya yang tradisioalkovensional selama ini, tidak akan dapat dipertahankan lagi.

Selanjutnya faseglobal dinilai sebagai fase yang belum tahu persis bagaimana formatnya yang utuh nanti, tetapi yang jelas era teknologi informasi, khususnya ditambah lajunya kemajuan transportasi udara, laut, dan darat mempercepat terwujudnya impian borderless society ini. Dalam era globa, fenomena globalisasi juga tampak di sini. Tradisi lokal dibawa ke aah global. Muslim diaspora, imigrasi muslim di Eropa, gerakan transnasionalisme menempati salah satu bagian dari kompleksitas kehidupan agama di era global ini. Apakah pada tempatnya yang baru di Eropa ini, para migraan muslim perlu menyusun dan menciptakan distem kehidupan keagamaan tersendiri, sebagai hasil adaptasi dengan lingkungan sekitar yang baru, ataukah mereka masih bersikukuh mempertahankan sistem aturan fikih lama, yang biasa digunakan dan dipraktikan di tempat-tempat yang dihuni oleh mayoritas muslim, baik di Timur Tengah, Pakistan atau Indonesia (Abdullah, 2009: 271-272).

Dalam pada itu Harun Nasution dengan menggunakan pendekatan sejarah membagi kehidupan manusia tiga periode, yaitu periode klasik (650-1250 M.) yang dibagi pada masa kemajuan Islam I (650-1000 M.), dan masa disintegrasi (1000$1250 \mathrm{M}$.), periode pertengahan (1250-1800 M.) yang diabgi ke dalam masa kemunduran I (1250-1500 M.),, dan Masa Tiga Kerajaan Besar yang dibagi pada fase kemajuan (1500-1700 M.) dan fase kemunduran II (1700-1800 M.), dan periode modern (1800 M. sd sekarang). Masa Kemajuan Islam I adalah masa ekspansi, integrase dan keemasan Islam; yaitu masa Nabi Muhammad SAW melaknakan visi, misi, tujuan dan sasaran dakwahnya yang kemudian dinilai sebagai yang paling berhasil; masa Khulaf'a al-Rasyidin (Abu Bakar, Umar, Usman dan Ali) yang mengintegrasikan fungsi kekhalifahan dan fungsi keagamaan yang ditandai dengan meletakkan dasar-dasar Islam dan persatuan umat; Bani Umayyah yang ditandai oleh perluasan wilayah dan kemajuan ilmu agama (Tafsir, Hadis, Teologi, Fikih, dan Sejarah Islam); dan ilmu umum; Bani Abbas yang ditandai oleh kemajuan ilmu umum, kebudayaan dan peradaban yang membawa dunia Islam pada zaman keemasan (Golden Age). Sedangkan pada periode pertengahan ditandai oleh kemunduran dalam bidang politik, ekonomi, ilmu pengetahuan, kebudayaan dan perabadan, serta infra struktur berupa serbuan Kulagu Khan yang menghancurkan kota Baghdad pada tahun $1258 \mathrm{M}$. Sedangkan periode modern adalaah periode kebangkitan Islam yang timbul setelah meneliti sebab-sebab kehancuran dunia Islam, serta kemajuan dunia Barat, seperti yang diperlihatkan oleh ekspedisi Napoleon di Mesir pada tahun 1801 yang membuka mata dunia Islam, terutama Turki dan Mesir (Harun, 1979:56-88) lihat juga (Frank, 2011).

Selanjutnya Alvin Toffler membagi tahap kehidupan manusia ke dalam masa agriculturalatau collision of waves, masaindustry atau the architecture of civilization, dan globalisasi atau the new synthesis (Alvin, 1980: 1-138). Tiga tahapan tersebut ditandai oleh kedaan sebagai berikut. Jika pada masa agricultural ditandai oleh orientasi kehidupan pada masa lampau, menggunakan teknologi sederhana, bekerja tanpa perencanaan, kurang menghargai waktu, pertemuan face to face, ukuran kekayaan pada tanah dan hewan ternak; maka pada masa industri dan globalisasi ditandai oleh oleh orientasi kehidupan pada masa sekarang dan yang akan datang, menggunakan teknologi modern, 
bekerja dengan perencanaan, amat menghargai waktu, pertemuan jarak jauh, ukuran kekayaan pada penguasaan ilmu dan teknologi, dan khusus pada era globalisasi ditandai oleh penggunaan teknologi informasi dan komunikasi yang canggih berupa kompoter, handphone, digital tecknology, dalam bentuk internet, small message system, facebook, wash app, you tobe, insta gram, dan sebagainya.

Terkait dengan pembagian periodesasi tersebut ada dua sikap atau pandangan. Pertama, sikap atau pandangan yang melihat bahwa periode tersebut terpisah-pisah satu persatu, yakni dengan adanya satu periode, maka periode lainnya tidak ada. Misalnya ketika saat ini umat Islam memasuki era globalisasi atau era millennial, berarti era lainnya:local, canonical, dan criritical, atau zaman klasik dan pertengahan sudah tidak ada lagi; atau ketika saat inimanusia memasuki era positivisme, maka era ideologis dan metafisis sudah tidak ada lagi, atau sudah ditinggalkan. Kedua, sikap yang memandang, bahwa periode tersebut semuanya ada secara bersamaan, bahkan saling terkait,namun dianut oleh masyarakat yang berbeda-beda. Yaitu bahwa di samping saat ini ada yang sudah memasuki era globalisasi, posivisme dan modern, namun masih ada pula yang masih berada pada tahap agricultural, ideologi, metafisis, local, dan canonical.

\section{Pandangan Islam tentang Periodesasi dan Era Millennial}

Selanjutnya jika pembagian tahap kehidupan manusia berdasarkan periodesasi tersebut dihadapkan pada pendidikan Islam yang berdasarkan al-Qur'an dan al-Sunnah, maka selain sebagian mengakui adanya tahapan zaman tersebut, namun Islam juga memiliki pandangan tersendiri tentang zaman. Islam misalnya mengakui adanya tahap teologis dan metafisis sebagaimana yang terdapat pada paham Augus Comte; dan mengakui pula adanya tahap local dan cannonical yang ditawarkanKeith Ward yang dikutip Amin Abdullah; tahap agricultural yang dikemukakan Alvin Toffler, zaman klasik dan pertengahan sebagaimana dikemukakan Harun Nasution. Islam menyuruh manusia untuk mempelajari semua zaman itu, namun hasilnya bisa sebagai inspirasi untuk dipratekkan di masa lalu, dan bisa juga sebagai peringatan untuk ditinggalkan (Nata, 2017: 173-174). Islam misalnya memperkenalkan zaman Jahiliyah yang harus ditinggalkan, karena mereka menganut sistem kepercayaan dan pola pikir yang keliru. Mereka yang menyembah patung berhala, atau kekuatan misteris dianggap perbuatan musyrik yang harus ditinggalkan. Namun Islam juga mengakui adanya khasiat atau keistimewaan pada benda-benda tertentu, namun bukan menjadikan benda-benda itu sebagai sesuatu yang disembah; melainkan yang disembah adalah pencipta benda-benda tersebut, yakni Allah SWT. Mereka yang berada dalam fase teologis dalam pahaam Comte, atau faselocal dalam fahamKeith Ward yang dikutip Amin Abdullah, dalam pandangan Islam disebut masa jahiliyah. Selanjutnya Islam menerima paham positivisme tapi tidak sepenuhnya, karena di dalam paham positivisme hanya mengakui yang dapat diamati oleh pancaindera, berupa hukumhukum alam atau hukum sebab akibat, serta hal-hal yang rational, sedangkan yang bersifat metafisik yang ghaib, yakni jiwa, spirit, dan sifat-sifat Allah SWT yang ada pada ciptaan atau fenomena tersebut, serta hal-hal yang hanya dapat diterima dengan kepatuhan dan ketundukan hati nurani, seperti kepatuhan pada ketentuan Tuhan dalam ibadah, dan kehidupan di akhirat, adalah bukan wilayah rational, tapi wilayah iman dan hati nunari. Dalam Islam terdapat hal-hal yang dapat dijangkau oleh pancaindera dan akal, sebagaimana dalam paham positvisme, dan terdapat pula hal-hal yang hanya dapat dijangkau oleh hati nurani dan iman, yakni dengan mempercayai dan menerima yang disampaikan Tuhan melalui wahyu-Nya; sekalipun tidak dapat dijangkau oleh pancaindera dan akal. Oleh karena itu dalam pendidikan Islam, pancaindera, akal dan hati nurani harus digunakan.

Selanjutnya jika dikaitkan dengan ayat alQur'an yang pertama turun, yakni surat al-'Alaq, 96: 15 yang pada intinyaa memerintah untuk membaca dan menulis dalam arti yang seluas-luasnya, termasuk melakukan penelitian dan melaporkan hasilnya dalam berbagai macam karya ilmiah dan produk terknologi, serta adanya ayat-ayat yang memerintahkan untuk melakukan klarifikasi, termasuk mempertanyakan dan mengkritisi atau tabbayun. Seperti ayat-ayat yang menyuruh meneliti dan menggunakan akal, seperti pada potongan ayat liyafakkaru (agar mereka berfikir), la'allaqum ta'qilun (agar menggunakan akal), afalaa yandzuruuna (agar mereka meneliti), yakni meneliti tumbuh-tumbuhan, binatang, benda-benda ruang angkasa, fenomena masyarakat, diri sendiri, dan firman Allah yang terdapat dalam al-Qur'an, menunjukkan bahwa ajaran Islam lebih memilih zaman canonical, critical, dan global. Kalaupun alQur'an juga terkadang berbicara untuk masyarakat local, teologis, dan agraris, namun hal itu sifatnya bukan tujuan akhir. Yang menjadi tujuan akhir adalah lahirnya masyarakat yang memiliki budaya baca tulis, bersikap kritis, mengembangkan ilmu pengetahuan, teknologi, kebudayaan dan peradaban, namun tetap berbasis pada tauhid, akhak mulia dan keseimbangan (Raghib, 2011: 269) Dengan landasan tauhid, ilmu, teknologi, kebudayaan dan peradaban yang dikembangkan manusia akan membawa dirinya makin dekat, makin patuh, makin tunduk dan makin cinta kepada Allah; dan dengan landasan akhlak mulia, ilmu pengetahuan, teknologi, kebudayaan dan peradaban, akan ditujukan untuk kesejahteraan, kemaslahatan dan kedamaian hidup manusia di dunia dan akhirat; dan dengan keseimbangan, lmu, 
teknologi, kebudayaan dan peradaban yang dikembangkan akan mencakup semua ilmu:ilmu agama, ilmu alam, ilmu sosial, filsafat dan ma'rifat. Itulah tugas yang harus dilakukan pendidikan Islam di era millennial, yaitu menanamkan dasar tauhid, akhlak mulia dan keseimbangan. Tugas lainnya adalah mengawal umat manusia dalam proses perubahan hidupnya dari satu tahap ke tahap lainnya dengan seimbang, serta meluruskan mereka yang masih berada pada tahap sebelumnya yaitu dengan landasan tauhid, akhlak mulia dan keseimbangan. Keadaan saat ini menunjukkan, bahwa keberadaan umat Islam masih berada pada tahaap lokal atau teologis. Hal ini misalnya tercermin pada sikap berhenti ketika telah dapat membaca, menghafal dan meyakini khasiat dari setiap ayat ayat yang dihafal dan dibacanya secara tektual. Sedangkan membaca dalam arti melakukan penelitian, mengkritisi, dan melahirkan berbagai teori dan konsep belum dapat dilakukan. Al-Qur'an, nampak terkesan "masih terlalu tinggi" buat umat Islam. Hal ini disebabkan karena ummat Islam belum melaksanakan amanat Rasulullah SAW agar menuntut ilmu sebagai alat untuk memahami al-Qur'an. Tugas dan peran pendidikan Islam dapat dilihat pada uraian di bawah ini.

\section{Potensi Pendidikan Islam Menghadapi Era Millenial}

Terdapat sejumlah potensi yang dimiliki pendidikan Islam dalam menghadapi tantangan di era millennialyang ciri-ciri serta hubungannya dengan era sebelumnya telah dikemukakan di atas. Potensi yang dimiliki pendidikan Islam dalam menghadapi era millineal tersebut antara lain terkait dengan sifat karakter pendidikan Islam yang holistik, komprehensif, dan progresif dan responsive, perhatian pendidikan Islam terhadap perbaikan karakter yang cukup besar,integralisme pendidikan Islam,pendidikan Islam dalam penyiapan generasi unggul, contoh dan keteladanan yang diberikan oleh Rasulullah SAW dalam menjalani kehidupan dalam berbagai situasi dan kondisi, pengalaman pendidikan Islam dalam menyiapkan sumber daya manusia yang unggul, pengalaman pendidikan Islam dalam menyiapkan lulusan yang berjiwa entrepreneur, dan perhatian pendidikan Islam pada manajemen modern. Berbagai potensi ajaran Islam tersebut dapat dikemukakan sebagai berikut:

\section{Sifat dan Karakteristik Pendidikan Islam}

Pada dasarnya sifat dan karakter pendidikan Islam adalah sama dengan sifat dan karakteristik ajaran Islam, yaitu ajaran yang didasarkan pada teologi humanism teo-prophetik. Dengan teologi ini, maka ajaran Islam selain mendasarkan ajaranya pada ajaran Tuhan yang terdapat di dalam al-Qur;an, dan ajaran Nabi Muhammad SAW yang terdapat di dalam hadisnya (ucapan, perbuatan dan ketetapan), juga berdasarkan pendapat akal pikiran yang sehat yang tidak bertentangan dengan ajaran al-Qur'an dan al-Hadis. Dengan demikian, di samping memelihara, menjaga dan mengamalkan ajaran yang bersifat perenialis, juga yang bersifat temporer yang dihasilkan para ahli, tokoh agama, peneliti, cendekiawan melalui kajian, penelitian dan sebagainya. Denga cara demikian fleksibilitas dan akomadatif terhadap berbagai perkembangna baru yang timbul di era milleneal termasuk yang menjadi salah satu ciri ajaran Islam. Dengan demikian, hal-hal baru yang dihasilkan era millennial yang sejalan dengan ajaran Islam dapat diterima. Sikap yang dinamis, inovatif, kreatif, dan berani keluar dari kebiasaan lama (out of the box) yang muncul di era millennial misalnya dapat diterima oleh ajaran Islam. Di dalam al-Qur'an dan al-Hadis terdapat nama-nama yang baik bagi Allah (Asmaul Husna) yang menurut hadis riwayat Turmuzi, berjumlah 99 atau 100 misalnya ,dan kita diminta oleh Allah dan Rasul-Nya agar meniru sifat-sifat-Nya itu, misalnya sifat almushawwir:memembentuk atau merubah sehingga kedaannya berbeda dengan sebelumnya (dinamis), sifat-Nya al-khaliq: menciptakan sesutu yang baru yang tidak ada contoh sebelumnya(inovafif); sifat almubdiu:memulai sesuatu yang baru atas usaha dan keinginan sendiri (kreatif); fan sifat albaari:memberikan keleluasaan untuk melakukan sesuatu tanpa terikat pada contoh sebelumnya. Selama ini, Asma al-Husna dipahami secara mistik, yakni dengan mengharapkan keberkahan, misalnya bahwa dengan membaca dan menghafalnya diharapkan memperoleh syafa'at (pertolongan) Tuhan di akhirat, atau agar dilapangkan dalam kuburnya dan sebagainya. Tentu saja sikap yang demikian tidak salah, dan boleh saja. Namun bersamaan dengan itu seharusnya pemahaman terhadap Asma al-Husna disertai dengan menangkap spirit atau etos kerja yang terdapat di dalamnya, sebagaimana yang telah diperlihatkan oleh Tuhan.

Sifat dan karakteristik pendidikan Islam berikutnya terkait dengan pandangannya terhadap waktu, era atau zaman. Islam mengakui adanya waktu yang berbeda-beda, kondisi dan situasi yang ada di dalamnya serta pengaruhnya bagi kehidupan manusia. Al-Qur'an misalnya memilih bulan Ramadhan sebagai bulan diwajibkannya berpuasa dan diturunkannya al-Qur'an, sebagaimana hal ini diabadikan dalam surat al-Baqarah, 2:185: (Beberapa hari yang ditentukan itu ialah) bulan Ramadhan, bulan yang di dalamnya diturunkan (permulaan) Al Quran sebagai petunjuk bagi manusia dan penjelasan-penjelasan mengenai petunjuk itu dan pembeda (antara yang hak dan yang bathil). Karena itu, barangsiapa di antara kamu hadir (di negeri tempat tinggalnya) di bulan itu, maka hendaklah ia berpuasa pada bulan itu. Selanjutnya, al-Qur'an menyatakan bahwa waktu siang sebagai saat berusaha mencari rezeki dan waktu malam sebagai 
saat beristirahat. Hal ini dinyatakan dalam surat anNabaAn-Naba,78:9-11:"Dan Kami jadikan tidurmu untuk istirahat; dan Kami jadikan malam sebagai pakaian; dan Kami jadikan siang untuk mencari penghidupan." Waktu malam dalam ayat tersebut diartikan pakaian,karena malam itu gelap menutupi jagat sebagaimana pakaian menutup tubuh manusia (Departemen Agama RI, 2006: 864). Selain itu, waktu sebagian dari waktu malam juga agar digunakan untuk bertahajjud. Hal ini dinyatakan dalam surat Al-Isra, 17:79:Dan pada sebahagian malam hari bersembahyang tahajudlah kamu sebagai suatu ibadah tambahan bagimu; mudahmudahan Tuhan-mu mengangkat kamu ke tempat yang terpuji." Dari beberapa ayat al-Qur'an yang dikutip tersebut dapat diketahui bahwa al-Qur'a mengakui adanya waktu, zaman dan periode yang berbeda-beda, baik situasi dan kondisi serta pengaruhnya bagi manusia.Namun demikian, alQur'an tidak mengakui adanya waktu sial atau waktu mujur. Semua waktu, zaman dan periode statusnya sama. Yang membedakan bukan waktunya, tapi penggunaan atau pemanfaatannya. Pada ayat-ayat tersebut Tuhan menggunakan waktu untuk menurunkan al-Qur'an, mewajibkan ibadah puasa, mengerjakan ibadah haji. Melaksanakan shalat tahajjud, berusaha mencari rezeki, beristirahat dan sebagainya. Hal ini sejalan dengan kandungan surat al-Ashr, 103:1-3: 1. Demi masa; 2. Sesungguhnya manusia itu benar-benar dalam kerugian; 3. kecuali orang-orang yang beriman dan mengerjakan amal saleh dan nasehat menasehati supaya mentaati kebenaran dan nasehat menasehati supaya menetapi kesabaran." Pada ayat tersebut al-ashr diartikan waktu, padahal sebenarnya kata al-ashr pada makna aslinya bukan waktu, tapi perasaan. Kata al-mu'shirat misalnya berarti perasan, seperti perasaan buahbuahan, atau juz, seperti perasaan buah jeruk, anggur, dan sebagainya. Penggunaan kata al-ashr untuk waktu dimasudkan agar waktu tersebut digunakan, atau dimanfaatkan dengan sebaik-baiknya, sebagaimana halnya buah-buahan yang diambil saripatinya dengan cara diperas. Penggunaan waktu tersebut untuk hal-hal yang positif, yakni meningkatkan keimanan, amal salih, berwasiat dengan kebenaran, dan berwasiat dengan kesabaran. Karena demikian pentingnya memanfaatkan waktu secara produktif untuk kebaikan, maka di kalangan para sahabat ada sebuah tradisi, yaitu apabila berpisah dari suatu pertemuan, maka mereka mengakhirinya dengan membaca surat al-Ashr. Karena demikian pentingnya memanfaatkan waktu secara positif dan produktif itu, maka Imam Syafi'i pernah berkata dalam sebuah pengandaian: Seandainya Tuhan tidak menurunkan surat lain di dalam al-Qur'an, kecuali al-Ashr, maka kandungan surat al-Ahr tersebut jika diamalkan dengan sebaikbaiknya, maka sudah cukup menjamin keselamatan manusia di dunia dan akhirat.
Sifat dan karakteristik pendidikan Islam terkait dengan penggunaan waktu, dapat pula dilihat daridari pesan Sayyidina Umar bin Khattab kepada para orang tua yang berbunyi: Didiklah anak-anakmu sekalian, karena mereka adalah makhluk yang akan hidup pada zaman yang berbeda dengan zaman kamu sekalian. Berdasarkan petunjuk Umar bin Khattab tersebut maka zaman atau era millennial dengan ciri-ciri dan tantangan-tantangannya sebagaimana tersebut di atas sudah harus diberitahukan kepada para peserta didik, dan sekaligus memberitahukan tentang wawasan, ilmu, keterampilan atau keahlian yang harus mereka miliki agar mereka dapat merubah tantangan-tantangan yang dihadapinya menjadi peluang serta mampu menggunakannya dengan tepat.

Selanjutnya terkait dengan respon al-Qur'an terhadap adanya zaman atau era teologis, metafisis, dan positifistik sebagaimana yang dikemukakan Augus Comte; atau era local, canonical, critical dan globalisasi sebagaimana dikemukakan Amin Abdullah, atau periode klasik, pertengahan, dan modern, terdapat penafsiran yang beragam. Sebagian berpendapat, bahwa al-Qur'an antara satu periode dengan periode lainnya sesungguhnya berjalan berdampingan, yakni ketiga atau keempat zaman atau era tersebut ada secara bersamaan, namun tempatnya berbeda-beda. Yakni ada masyarakat yang masih pada periode yang masih berada pada tahap teologis, metafisis atau positifitik; periode local, canonical, critical dan globalisasi, atau periode klasik, pertengahan atau modern; agricultural, industrial, atau globalisasi. Hal ini tercermin dari adanya kandungan ayat-ayat, atau metode yang cocok untuk orang yang hidup setiap zaman, Misalnya ada masyarakat yang dapat didekati dengan pemahaman yang berbentuk hikmah, yakni dengan mengemukakan kebaikan-kebaikan atau manfaat yang terdapat dalam ajaran (al-hikmah), berupa pahala atau kebaikan dan manfaat lainnya; atau dengan mengemukakan bimbingan dan nasehat yang baik (ma'uidzah hasanah), atau dengan cara berdialog dengan cara yang baik (mujadalah bil laity hisa ahsan). Sejalan dengan pendapat ini, maka istilahnasakh mansukh ayat-ayat al-Qur'an, yakni ayat yang dibatalkan atau tidak diberlakukan isinya (al-mansukh), yakni ayat yang turun lebih dahulu, dan ayat yang membatalkan (al-nasikh) yang datang kemudian tidak diakui adanya. Semua ayat al-Qur'an tetap berlaku sesuai keadaan waktu, zaman dan periode dan sifat-sifat yang dimiliki orang tersebut. Sementara itu ada pula yang berpendapat, bahwa zaman atau periode itu berbeda-beda dan antara satu dan lainnya tidak berjalan bersamaan. Atau setidaknya zaman-zaman itu tetap ada, namun alQur'an memilih zaman tertentu yang cocok dan digunakan untuk menyampaikan gagasan, pemikiran dan ajaran al-Qur'an. Dalam hal ini sebagian ahli ada yang berpendapat, bahwa al-Qur'an diturunkan 
bukan pada zaman local yang mengandalkan kepercayaan atau perasaan yang sulit terukur, melainkan diturunkan pada zaman canonical dan critical, yakni zaman baca tulis dan berfikir kritis. Hal ini terlihat dari adanya ayat yang pertama kali diturunkan yang berisi perintah memba dan menulis, sebagaimana terlihat dalam surat al-Alaq, 96:1-5: "Bacalah dengan (menyebut) nama Tuhanmu Yang menciptakan; 2. Dia telah menciptakan manusia dari segumpal darah; 3. Bacalah, dan Tuhanmulah Yang Maha Pemurah; 4. Yang mengajar (manusia) dengan perantaran kalam; 5. Dia mengajar kepada manusia apa yang tidak diketahuinya." Kosakata Iqra' yang berarti baca, bukan hanya mengandung arti membaca huruf-huruf atau angka-angka dalam bentuk katakata atau kalimat sebagaimana yang dipahami, melainkan mengandung arti research (penelitian), baik penelitian bayani (eksploratif dengan mengandalkan kemampuan bahasa), 'irfani (pembersihan diri dengan mengandalkan intuisi yang bersih yang siap menerima ilmu dari Tuhan, ijbari (penggunaan eksperimen dengan mendandalkan pancaindera), , burhani (observasi dan demontrasi argumentative) atau jadali (logika deduktif dan induktif) (Nata, 2017). Hal ini sejalan dengan makna generic al-iqra, yakni mengumpulkan atau menghimpun. Hal ini sama artinya dengan research yang berarti menemukan. Perintah melakukan penelitian ini dapat pula dipahami dari ayat-ayat alQur'an yang menyuruh manusia melakukan intidzar, seperti pada surat al-Ghasiyah, 88:17-20:17. "Maka apakah mereka tidak memperhatikan unta bagaimana dia diciptakan; 18. Dan langit, bagaimana ia ditinggikan; 19. Dan gunung-gunung bagaimana ia ditegakkan; 20. Dan bumi bagaimana ia dihamparkan. "Pada ayat tersebut terdapat perintah meneliti dunia fauna yang diwakili oleh penelitian terhadap unta; penelitian ruang angkasa (langit), penelitian terhadap gunung (geologi), dan penelitian terhadap bumi. Hasil-hasil penelitian tersebut berupa teori-teori yang setelah divalidasi dan diverifikasi disusun secara sistematik kemudian menjadi ilmu pengetahuan, dan setelah dipadu dengan teknik, maka terjadilah teknologi yang dapat digunakan untuk memanfaatkan sumber daya alam untuk kemakmuran manusia. Selanjutnya kosakata bi alqalam yang secara harfiah berarti dengan pena, mengandung arti tentang pentingnya menyiapkan alat-alat yang berkaitan dengan alat untuk menyimpan hasil-hasil penelitian, berupa tulisan, buku, rekaman, disket, plasdisk, photo, disain, dan sebagainya, yang suatu saat hasil-hasil penelitian tersebut dapat diakses untuk jangka waktu yang tidak terbatas. Sedangkan dengan sikap critical dapat dilihat dari ayat-ayat yang memerintahkan manusia agar menggunakan menggunakan pikiran (liyatafakkaru), menggunakan akal (la'allakum ta'qilun), agar melakukan perenungan (liyatadabbarun), dan sebagainya. Jika teori yang kedua ini yang digunakan, maka teori tentang nasakh mansuk ayat-ayat al-Qur'an dapat diterima. Ayat yang datang kemudian dapat menghapus ayat yang datang kemudian, jika kedua ayat tersebut secara lahiriyah nampak bertentangan.

Menghadapi perbedaan sudut pandang terkait dengan waktu tersebut, nampaknya menarik dan perlu diperhatikan sikap yang dikemukakan Amin Abdullah yang mengusulkan agar memadukan antara pemikiran yang bercorak lokal yang mengandalkan perasaan, spiritualitas, ritualitas, yang berdasarkan pada tradisi lisan yang berada di bawah kordinasi tokoh adat, yang tercermin dalam keteguhan menjalan ajaran agama dan tradisi lokal dengan pemikiran yang bercorak canonical dan critical sebagaimana tercermin pada masyarakat terpelajar dan terdidik yag berdasarkan teori dan temuan ilmiah yang tercermin dalam tradisi menulis dan mengkitisi untuk mencari yang terbaik; dan kemauan untuk menerima isu-isu baru di era globalisasi sebagai akibat dari kemajuan ilmu pengetahuan dan teknologi modern, dengan membangun sinergitas dan integrasi antara berbagai disiplin ilmu pengetahuan (Abdullah, 2005).

Dengan demikian dapat diketahui bahwa pendidikan Islam yang berideologi hamanisme teoprophetik memandang perlunya memilih waktu yang tepat dan memanfaatkannya secara produktif untuk hal-hal yang positif. Pendidikan Islam juga mengajarkan tentang perlunya menyampaikan kandungan pendidikan sesuai dengan tahapan zaman di mana manusia itu berada. Sikap dan pandangan yang diajarkan pendidikan Islam yang demikian itu sejalan dengan tantangan yang terjadi pada era millennial. Dengan kata lain, pandangan ajaran Islam yang demikian itulah yang seharusnya dianut oleh masyarakat yang hidup di era millennial.

\section{Perhatian Pendidikan Islam terhadap Perbaikan Karakter}

Tanggung jawab pendidikan Islam dalam memberikan bimbingan pada manusia dalam menghadapi era millennial juga dapat dilihat dari perhatian pendidikan Islam terhadap pendidikan atau perbaikan karakter. Mohammad Athiyah al-Abrasyi misalnya mengatakan:

Pendidikan budi pekerti adalah jiwa dari pendidikan Islam, dan Islam telah menyimpulkan bahwa pendidikan budi pekerti dan akhlak adalah jiwa pendidikan Islam. Mencapai suatu akhlak yang sempurna adalah tjuan sebenarnya dari pendidikan. Tapi ini tidak beraryi bahwa kita tidak mementingkan pendidikan jasmani atau akal atau ilmu ataupun segi-segi praktis lainnya, tetapi artinya ialah bahwa kita memperhatikan segi-segi pendidikan akhlak seperti juga segi-segi lainnya itu. Anak-anak membutuhkan kekuatan dalam jasmani, 
akal, ilmu dan anak-anak membutuhkan pula pendidikan budi pekerti, perasaan, kemauan, cita-rasa dan kepribadian. (Mohd. 'Athitah. 1974, 15)

Dalam pendidikan Islam kosakata karakter biasanya disebut dengan akhlaq yang secara harfiah berarti perangai, tabi'at, prilaku, sikap, budi pekeri. Kata akhlak dekat dengan khalaq artinya penciptaan, dan dekat dengan kata makhluq yang berarti yang diciptakan. Hal ini menunjukkan bahwa akhlak merupakan hiasan bagi makhluk, atau sesuatu yang harus dilakukan oleh makhluk ciptaan Tuhan sebagai Khaliq (Maha Pencipta). Selanjutnya dari definisi akhlak yang dikemukakan Ibn Miskawaih dan alGhazali: yakni ekpresi jiwa yang muncul dengan mudah tanpa memerlukan pemikiran dan pertimbangan, dapat diketahui bahwa sesuatu dapat dikatakan akhlak apabila telah memiliki lima ciri, yaitu: sudah mandarah daging, sudah mudah dan gampang dilakukan; dilakukan atas kemauan sendiri; dilakukan dengan sebenarnya, dan diniatkan karena Allah SWT (Nata, 2015, 4-6).

Selanjutnya dengan mengacu pada surat alNahl, 16:78: "Dan Allah mengeluarkan kamu dari perut ibumu dalam keadaan tidak mengetahui sesuatupun, dan Dia memberi kamu pendengaran, penglihatan dan hati, agar kamu bersyukur." Kosakata al-sam'a atau pendengaran adalah representasi dari pancaindera. Al-Qur'an menggunakan kosatakata al-sam'a sebagai sampling dari pancaindera lainnya, karena di antara pancaindera yang lima, pendengaranlah yang pertama kali berfungsi, dan tepatnya tujuh jam setelah bayi dilahirkan, pendengaran sang bayi sudah berfungsi dengan baik, dan itulah sebabnya yang pertama kali dilakukan terhadap bayi adalah dengan memperdengarkan suara azan pada telinganya. Dengan disebutnya al-sama dimaksudkan semua pancaindera yang lainnya termasuk. Al-Qur'an tidak menyebut semua pancaindera, karena terkait dengan sifat dan karakter ajaran al-Qur'an yang bersifat ijaz, yakni singkat dan padat. Dari penggunaan pancaindera dapat dihasilkan pengetahuan yang bersifat empiris yang kemudian dipraktekkan hingga menjadi budi pekerti, budaya atau atau adat itiadat yang di dalamnya terdapat nilai-nilai baik dan buruk. Sedangkan kosakataabshar yang terdapat pada potongan ayat tersebut dapat diartikan penglihatan, namun bukanlah penglihatan dengan mata kepala melainkan dengan akal pikiran. Melihat dengan mata kepala biasanya menggunakan kosakata nadzara. Dengan menggunakan pemikiran manusia dapat menentukan tentang yang baik dan buruk yang selanjutnya disebut dengan etika. Selanjutnya kosakata afidah yang terdapat pada ayat tersebut dapat diartikan hati nurani yang selalu jujur dan lurus. Melalui hati inilah dapat ditentukan baik atau buruk yang selanjutnya dikenal dengan moral.

\section{Hasil Penelition}

Dengan demikian terdapat berbagai sumber tentang baik dan buruk. Ada baik dan buruk berdasarkan pancaindera yang disebut budi pekerti, budaya atau adat istiadat, ada baik dan buruk berdasarkan akal yang disebut etika; dan ada yang baik dan buruk berdasarkan hati nurani yang disebut moral. Karena Islam menerima pendapat pancaindera, akal, dan hati nurani, maka ajaran Islam menerima adat istiadat, budi pekerti, budaya, etika dan moral dalam batasbatas yang sejalan dengan al-Qur'an dan al-Sunnah. Jika ajaran akhlak Islam yang berdasarkan al-Qur'an dan hadis bersifat universal, general, mutlak benar, dan berlaku sepanjang zaman, maka ajaran baik dan buruk yang berasal dari pancaindera (adat istiadat, budi pekerti dan budaya), dari akal pikiran (etika), dan hati nurani (moral) bersifat lokal, spesifik, nisbi dan bisa tidak berlaku. Ajaran baik buruk yang berupa etika yang berdasar pada akal sebagaimana yang berlaku di Barat misalnya, hanya berlaku di Barat saja, dan bisa dibatalkan. Namun demikian, ajaran baik dan buruk yang bersumber dari adat istiadat, budi pekerti, budaya, etika dan moral tetap diterima oleh akhlak Islam sebagai alat untuk menafsirkan dan melaksanakannya. Dengan demikian, di samping memilikisi sisi universal, akhlak Islam juga memiliki sisi lokal. Sebagai contoh, akhlak Islam tentang menutup aurat adalah universal dan berlaku sepanjang zaman. Namun cara menutup aurat tersebut dapat menggunakan tradisi, budaya dan budi pekerti yang terdapat di setiap daerah, seperti Jawa, Sunda, Betawi, Sumatera Barat, Sumatera Utara dan sebagainya dapat digunakan untuk mempraktekkan cara menutup aurat sebagaimana yang dikehendaki al-Qur'an dan alHadis. Namun demikian, ad acara-cara model menutup aurat yang tidak diterima oleh Islam karena tidak sejalan dengan pesan ajarab menutup aurat yang dikendaki oleh Islam, yakni memelihara kesopanan, menghindari fithnah, memuliakan manusia, dan menghindari perbuatan maksiat, perkosaan dan kemorosotan akhlak. Dengan demikian ajaran akhlak Islam bersifat militansi moderat. Yakni dari satu sisi terbuka dan akomodatif, namun dari sisi lain tetap militant, dalam arti tidak menerima perubahan.Dengan demikian akhlak Islam dapat menerima ajaran baik buruk yang berasal dari etika barat, ajaran moral dari tokoh spiritual, atau yang berasal dari peraturan perundangan yang dibuat pemerintah, dengan cara yang selektif melalui proses tabayyun(penjelasan), atau tatmim (penyempurnaan), sebagaimana yang dilakukan oleh Nabi Muhammad SAW yang menyatakan: bahwa ia diutus untuk menyempurnakan akhlak yang mulia. Kosakata menyempurnakan dalam hadis tersebut menggambarkan bahwa Nabi bukan hanya menghargai, melainkan menerima akhlak yang mulia yang pernah ada sebelumnya, yakni akhlak yang berasal dari etika Yunani, moralitas ajaran Sidharta Gautama, tradisi atau budaya China, India, Persia dan 


\section{Hasil Penelition}

sebagainya dengan cara yang selektif. Tentang apa saja yang dikatakan baik, banyak teori yang mengemukakan dengan nama yang berbeda-beda. Menurut Yunani Kuno, sebagaimana dikutip Thomas Lickono, ada 10, yaitu; (1) hikmah, kebijakan atau wisdom, (2) keadilan (justice); (3) kebajikan (fortitude), (4) pengendalian (temperance); (5) cinta; (6) sikap positif (husn al-dzann); (7) bekerja keras; (8) integritas, (9) syukur dan (10) rendah hati (Lickona, 2015, 16-20).

Ajaran akhlak Islam ini tidak hanya terkait hubungan dengan Tuhan, melainkan hubungan dengan manusia yang hidup dalam zaman yang berubah-ubah. Yaitu akhlak yang berkaitan dengan kehidupan sosial, ekonomi, politik, budaya, pendidikan, dan lain sebagainya. Sikap-sikap yang ditunjukkan generasi millennial sebagaimaa tersebut di atas, yakni: Suka dengan kebebasan, senang melakukan personalisasi, mengandalkan kecepatan informasi yang instant, suka belajar, bekerja dengan lingkungan inovatif, aktif berkolaborasi, hyper technology, terbiasa berfikir out of the box, sangat percaya pada diri sendiri dan berani mengungkapkan pendapat tanpa ragu, pandai bersosialisasi, serba instant, mengandalkan pada kemudahan IT, ketergantungan yang tinggi pada internet dan media sosial, menjadi pribadi yang malas, tidak mendalam, tidak membumi, cenderung lemah dalam nilai-nilai kebersamaan, kegiatan gotong royong, kehangatan lingkungan dan kepedulian sosial, cenderung keBarat-baratan, tidak memperhatikan etika dan aturan formal, adat istiadat serta tata karma (Muhammad, 2017, 7).

Jika sikap-sikap yang ditimbulkan generasi millennial ini dilihat dari ajaran akhlak Islami, maka nampak sebagian dari sikap-sikap tersebut ada yang sejalan dengan ajaran akhlak Islami, dan ada yang tidak sejalan. Sikap suka belajar, bekerja dengan lingkungan inovatif, aktif berkolaboras, berani mengungkapkan pendapat tanpa ragu, pandai bersosialisasi adalah sejalan dengan akhlak Islami dan karenanya perlu penguatan. Sedangkan sikap menjadi pribadi yang malas, tidak mendalam, serba instant, tidak membumi, cenderung lemah dalam nilai-nilai kebersamaan, kegiatan gotong royong, kehangatan lingkungan dan kepedulian sosial, cenderung ke-Barat-baratan, tidak memperhatikan etika dan aturan formal, adat istiadat serta tata krama, menjadi pribadi yang malas, tidak mendalam, tidak membumi termasuk akhlak yang tidak baik. Selanjutnya hyper technology, dan berfikir out of the box, bisa membawa pada kebaikan dan bisa membawa pada keburukan. Dalam hubungan ini, maka tugas pendidikan Islam adalah mencegah masuknya pengaruhnilai-nilai dan sikap-sikap yang negative ke dalam diri peserta didik dan mengarahkan sikap yang bisa negative dan positif yang ditimbulkan era millennial tersebut; serta menguatkan nilai-nilai yang positif.
Nilai-nilai dan sikap positi yang ditimbulkan di era milenial yaitu, suka belajar, bekerja dengan lingkungan inovatif, aktif berkolaboras, berani mengungkapkan pendapat tanpa ragu, pandai bersosialisasi selain sejalan dengan akhlak Islami, juga ada yang sejalan dengan nilainilai yang dikembangkan dalam pendidikan karakter di Indonesia yang berasal dari empat sumber, yaitu agama, Pancasila, budaya, dan tujuan pendidikan nasional, yaitu sikap kerja keras, kreatif, mandiri dan demokratis, rasa ingin tahu, dan menghargai prestasi (Zubaedi, 2011, 75-76). Sedangkan nilainilai dan sikap negative yang ditimbulkan di era millennial, yaitu malas, tidak mendalam, serba instant, tidak membumi, cenderung lemah dalam nilai-nilai kebersamaan, kegiatan gotong royong, kehangatan lingkungan dan kepedulian sosial, cenderung ke-Barat-baratan, tidak memperhatikan etika dan aturan formal, adat istiadat serta tata krama, menjadi pribadi yang malas, tidak mendalam, tidak membumi termasuk akhlak yang tidak baik dan betentangan dengan nilai-nilai pendidikan karakter di Indonesia, yaitu religious, toleransi, bersahabat/komunikatif, gemar membaca, peduli lingkungan dan peduli sosial. Dengan demikian nilainilai pendidikan karakter di Indonesia tidak hanya mendukung sikap-sikap yang ditimbulkan di era millennial dan juga bersikap mencegah. Namun demikian sikap bekerja dengan lingkungan inovatif, aktif berkolaboras, berani mengungkapkan pendapat tanpa ragu, dan pandai bersosialisasi sebagaimana ditimbulkan di era millennial adalah sejalan dengan nilai-nilai pendidikan karakter yang berkaitan dengan kerja keras, kreatif, mandiri, demokratis, rasa ingin tahu, dan gemar membaca. Dengan demikian, nilainilai pendidikan karakter di Indonesia sejalan dengan nilai-nilai yang ditimbulkan di era millennial.

Nilai-nilai dan sikap yang ditimbulkan di era millinneal juga ada yang sejalan dengan nilai-nilai yang terdapat pada program Living Values Education (LVE) yang ditawarkan Diane Tilman dan digunakan oleh Perserikatan Bangsa-bangsa (PBB) pada ulang tahunnya yang ke-50 pada tahun 1995. Yaitu nilai kedamaian, penghargaan, cinta, kerjasama, kebahagiaan, kejujuran, rendah hati, tanggung jawab, kesederhanaan, toleransi, kebebasan, dan persatuan (Hidayatulloh, 2018, 128-144). Nilai-nilai yang terdapat dalam LVE lebih banyak yang sejalan dengan nilai-nilai yang terdapat dalam era millennial. Dengan demikian, nilai-nilai dalam LVE sudah sejalan dengan nilai-nilai yang ditimbulkan di era millennial.

Hal yang terpenting yang harus dilakukan Pendidikan Islam adalah mengupayakan agar nilainilai yang terdapat dalam akhlak Islam, nilai-nilai pendidikan karakter di Indonesia, dan nilai-nilai yang terdapat dalam Living Values Education (LVE) benar-benar tertanam kuat dalam generasi yang hidup di era millennial. Hal ini menarik dikemukakan, 


\section{Hasil Penelition}

karena selama ini banyak kritik bermuncullan yang ditujukan terhadap kegagalan pendidikan karakter. Para mengeritik pendidikan karakter di Amerika misalnya mengatakan: bahwa pendidikan karakter kurang menaruh perhatian pada kebajikan-kebajikan tertentu, bahwa ia dibatasi, terbatas, dan berfokus pada metode pengajaran tradisional (Nucci, 2015, 129). Meningkatkan perilaku menyimpang, kriminalitas, korupsi, narkoba, sek bebas, dan lain sebagainya sering digunakan sebagai indicator kegagalan pendidikan karakter. Penyebab terjadinya keadaan yang demikian yang umumnya digunakan sebagian para ahli adalah karena pendidikan karakter berhenti pada pengajaran yang bersifat wawasan, pengetahuan, hafalan yang bersifat kognitif dan indoktrinasi, tidak adanya contoh dan teladan, latihan dan pembiasaan, dan bersifat kuantitatif.

Seiring dengan itu, muncul pula sejumlah pendekatan yang dinilai efektif untuk membentuk karakter yang mulia. Zubaedi misalnya menawarkan delapan pendekatan, yaitu evocation, inculcation, moral reasoning, value clarificiation, values analysis, moral awareness, commitment approach, dan union approach (Zubaedi, 207). Pertama, evocation adalah pendekatan yang memberi kesempatan dan keleluasaan kepada peserta didik untuk secara bebas mengekpresikan respon afektifnya terhadap stimulus yang diterimanya. Kedua, inculcation adalah pendekatan agar peserta didik menerima stimulus yang diarahkan menuju kondisi siap. Ketiga, moral reasoning adalah pendekatan yang terjadi transaksi intelektual taksonomik tinggi dalam mencari pemecahan suatu masalah. Keempat, value clarification adalah pendekatan melalui stimulus terarah agar peserta didik diajak mencari kejelasan isi pesan keharusan nilai moral. Kelima, value analysis adalah pendekatan agar peserta didik dirangsanh untuk melakukan analisis nilai moral. Keenam, moral awareness adalah pendekatan agar peserta didik menerima stimulus dan dibangkitkan kesadarannya akan nilai tertentu. Ketujuh, commitmen approach adalah pendekatan agar peserta didik sejak awal diajak menyepakati adanya suatu pola pikir dalam proses pendidikan nilai. Kedelapan, union approach adalah pendekatan agar peserta didik diarahkan untuk melaksanakan secara riil nilai-niai budi pekerti dalam suatu kehidupan.

Selanjutnya ada pula yang berpendapat bahwa di antara sebab terjadinya kegagalan dalam pendidikan karakter adalah karena kesalahan dalam menerapkan konsep pendidikan Islam. Moeslim Abdurrahman misalnya mengatakan:

Salah satu kritik yang mungkin sudah hamper klasik, tentang pendidikan (Islam) ialah belum ditemukannya pengetahuan pedagogis agama yang memadai. Apa yang selama ini dilaksanakan tentang pendidikan agama mungkin tidak lebih dari proses belajar mengajar agama. Itu mungkin juga lebih tepat disebut "transmisi pengetahuan agama”, melalui cara didaktis-metodis seperti halnya pengajaran umum. Oleh karena itu, jika kita ingin menemukan pedagogis Islam, barangkali yang harus kita lakukan ialah merumuskan lebih dahulu tentang filsafat pendidikan Islam yang kemudian dijadikan dasar mengembangkan cara-cara teknis pendidikan, baik dalam lingkup sekolah maupun keluarga dan masyarakat, atau dijadikan acuan model pedagogis dalam penyelenggaraan pendidikan Islam. Misalnya bagaimana gambaran filosofis konsep nilai yang selama ini kita sebut "anak yang shaleh" atau "insan kamil" (Abdurrahman, 1997, 239240).

Sejalan dengan itu, Moeslim Abdurrahman menganjurkan sebaiknya pendidikan agama harus lebih berorientasi untuk menumbuhkan wawasan keagamaan dalam kaitan dengan religious intellectual building. Oleh karena itu, selain mungkin lebih cocok disajikan dalam kelas-kelas seminar dan evaluasi melalui karya tulis, materi kuliah agama itu hendaknya bersifat "perspektif". Misalnya Islam dalam perspektif kebudayaan, dalam perspektif sejarah, dalam perspektif perkembangan sains, dan lain sebagainya. Selain yang mungkin tidak kalah pentingnya ialah dengan cara-cara memperoleh "suasana religiousitas," misalnya dengan life in pesantren pada saat-saat tertentu. Selain itu dengan melakukan kunjungan sosial, seperti ke rumah jompo, ke lokasi bencana alam, ke permukiman kumuh, Sejalan dengan itu, tiga komponen dasar pendidikan agama-guru, filsafat dan metodologi pendidikan dan perangkat keras (gedung dan lain sebagainya) harus serempak dikembangkan (Abdurrahman, 1997, 242-243).

Pendapat tersebut sesuai pula dengan strategi yang diitawarkan oleh Diane Tilmlman yang menggagas living values education. Ia misalnya mengatakan, bahwa salah satu konsep filosofis yang mendasar dalam LVE adalah setiap peserta didik diajak untuk mereflesikan dan menggali nilai pribadi mereka, agar menjadi pondasi dalam menciptakan suasana belajar yang berbasis nilai, seperti mengajak peserta didik dalam menyusun perencananaan pembelajaran dengan melakukan refleksi terlebih dahulu pada dirinya. Dengan living vales education diarahkan untuk membantu seseorang menghidupkan nilai-nilai yang sudah ada dalam diri setiap orangm seperti damai, menghargai, kasih sayang, kerjasama, kebahagiaan, kejujuran, kerendahan hati, tanggung jawab, kesederhanaan, toleransi, kebebasan daan persatuan (Hidayatulloh, 152).

Selain itu ada pula yang menawarkan implementasi pendidikan Islam dengan pendekatan filosofism induksi-deduksi, kultural, fungsional, dan emosional. Pendekatan filosofis adalah sebagai studi 
proses tentang kependidikan yang didasari dengan nilai-nilai ajaran Islam menurut konsepsi filosofis bersumberkan kitanb suci al-Qur'an dan sunnah Nabi Muhamad SAW. Pendekatan induksi adalah pendekatan yang penganalisaannya secara ilmiah, bertolak dari kaidah-kaidah khusus untuk menentukan hukum yang bersifat umum. Sedangkan pendekatan deduksi adalah sebaliknya, dari yang umum menuju yang khusus. Sedangkan pendekatan sosio kultural bertolak dari pandangan bahwa manusia sebagai makhluk sosial, tolong menolong antar sesame manusia, kesatuan masyarakat, dan persaudaraan. Sedangkan pendekatan fungsional menekankan peran dan manfaat manusia; dan pendekatan emosional menekankan pada upaya menggugah perasaan dan emosi peserta didik (Ismail, 2013, 37-38).

Terlepas dari konsep-konsep dan pendekatan tersebut di atas, sesungguhnya ada bahan rujukan yang dapat digunakan sebagai bahan rujukan dalam pendidikan karakter, yaitu adanya success story yang dicapai oleh Nabi Muhammad SAW, Jepang dan Finlandia. Nabi Muhammad tercatat dalam sejarah sebaagai yang paling berhasil dalam mengemban misi risalahnya membina akhlak mulia, sebagaimana yang ada di dalam al-Qur'an: Kaana khuluquhu al-Qur'an. Allah SWT menyatakan: Sungguh pada diri Nabi Muhammad SAW terdapat ketauladan yang baik; Allah juga menyatakan: Sesungguhnya Engkau berbudi pekerti yang mulia. Berdasarkan petunjuk surat al-Fath, ayat 19, bahwa kesuksesan Nabi Muhammad SAW dalam membina akhlak itu karena tegas dan tidak mau kompromi terhadap kekafiran, kasih sayang dengan sesame manusia, selalu memohon petunjuk Allah, mengharapkan keridoan-Nya, dan ikhlas. Ia juga memberikan contoh teladan yang baik; membimbing, melatih, membiasakan, dan teguh. Sedangkan Jepang berhasil membina akhlak melalui pendidikan etika dan penegakkan hukum. Sedangkan Finlandia berhasil melalui pendidikan yang dilaksanakan secara berkualitas.

Berdasarkan uraian tersebut dapat diketahui bahwa pendidikan Islam amat menekanian akhla mulia yang sejalan dengan akhlak yang harus dimiliki masyarakat di era millennial. Yaitu akhlak yang bersifat militansi moderat. Yakni berpegang teguh pada ajaran syari'at sebagaimana ditetapkan alQur'an dan al-Sunnah, namun dalam pelaksanaanya dapat berkolaborasi dengan etika, moral, budi pekerti, budaya dan adat istiadat. Dengan demikian, dalam rangka membentuk akhlak mulia, selain dapat menggunakan petunjuk al-Quran, al-Sunnah, khususnya kesuksesan Nabi Muhammad SAW, juga dapat mengambil inspirasi dari yang dilakukan bangsa-bangsa lain di dunia, seperti Finlandia dan Jepang. Sifat dan karakteristik pendidikan Islam yang memberikan perhatian terhadap pembentukan karakter yang mulia, dapat digunakan pendidikan
Islam dan menyiapkan manusia yang siap menghadapi era millennial.

\section{Integralistisme Pendidikan Islam}

Karakter Integralistik yang terdapat dalam pendidikan Islam dapat pula dijadikan alternative dalam menyiapkan manusia yang siap menghadapi era millennial. Sebagaimana telah dikemukakan di atas, bahwa era millennial antara lain ditandai oleh adanya generasi yang memiliki ciri aktif berkolaborasi, dan terbiasa berfikir out of the box. Generasi millennial tidak mau lagi dikurung oleh suatu pandangan tertentu, melainkan ia akan terus menjelajah, membuka diri, berintegrasi dengan semua aliran, pemikiran, pandangan, gagasan dan sebagainya dalam rangka memperoleh jawaban atas problema kehidupan yang kompleks. Sikap esklusif, dan sectarian misalnya harus diganti dengan sikap inklusif dan toleran. Dalam upaya merespon kebutuhan generasi millennial yang salah satu wataknya yang demikian itu, maka pendidikan harus mengembangkan karakter integralistiknya dengan perspektif yang baru. Jika di zaman klasik umat Islam berkolaborasi atau mengintegrasikan pandangan al-Qur'an dengan llmu pengetahuan Yunani, India, China, Persia dan lainnya, maka di era Millennial integrase tersebut tidak memadai lagi. Integrasi di masa sekarang, integrasi harus dilakukan dengan ilmu pengetahuan modern dengan terlebih dahulu menghilangkan prinsip-prinsipnya yang tidak sejalan dengan prinsip Islam, seperti prinspnya yang hanya mengakui yang rational dan empiris dengan ditambah dengan yang metafisis (al-ghaib). Selanjutya jika di masa klasik masing-masing bidang llmu, seperti kalam, filsafat dan tasawuf memberikan jawaban sendiri-sendiri atas berbagai persoalan umat, maka di masa sekarang ketiganya harus dipadukan. Karakter integralisme pendidikan Islam ini lebih lanjut dapat dipahami dari gagasan dan pemikiran yang dikemukakan Armahedi Mazhar. Dalam hubungan ini ia mengatakan:

Integralisme dapat digunakan sebagai filsafat yang menjembatani kebenaran-kebenaran diniyaha yang tercantum dalam Kitab Suci Qur'an dengan kebenaran-kebenaraan ilmiah yang terbaca dalam Kitab Besar Alama semesta seperti halnya filsafat tradisional Islam di zaman dahulu. Kita perlu berusaha mengganti filsafat Islam tradisional yang menghubungkan ilmu pengetahuan Yunani Helenistik dengan Qur;an Suci dengan suatu filsafat Islam modern yang menghubungkan ilmu pengetahuan modern dengan Qur'an Suci. Integralisme harus dikembangkan dengan suatu tradisi kritis, generasi demi generasi, sehingga dapat menjadi apa yang disebut Alvin Toffler supraideologi bagi peradaban Islam di masa depan. Integralisme melihat adanya kesatupaduan antara manusia-alam-Tuhan, atau Allah, alam-manusia. Hal ini sesuai dengan "diri-cakrawaala-kebenaran" atau 
:anfus-afaq-Haqq." Atau antara alam Lahut, alam jabarut, alam malakut-alam nasut (Alam Tuhan, alam jagat raya, alam ghaib dan alam nyata; Allah-Rabb al-Falaq-Rabb an-Naas yang muncul dalam ayat pertama surat terakhir Qur'an Suci, yaitu Surat alIkhlas, al-Falaq dan An-Naas (Mahzar, 1983, 130137).

Dengan integralisme ini akan memunculkan ilham-ilham Ilmiah di dalam pikiran para ilmuwan Muslim sehingga mereka mampu menggali kandangan-kandungan makna dalam al-Qur'anul Karim untuu kemudian dikembangkan sebagai penemuan-penemuan ilmiah baru. Bukan sebaliknha seperti selama ini di mana ayat-ayat Qur'an dicaricari untuk menjelaskan penemuan ilmiah atau teknologi baru kemudian digembarkan gemborkan bahwa: "semuanya sudah ada di dalam Qur'an." Selama sikap yang disebut belakangan ini yang diambil oleh para ilmuwan Muslim, mereka akan tetap menjadari tertawaan dunia ilmu pengetahuan modern, karena tidak bisa menyumbangkan apa-apa kecuali berteriak "semua sudah ada dalam al-Qur'an" untuk menutupi kompleks rendah diri mereka. Tetapi untunglah ilmuwan Muslim tidak semuanya bersikap demikian, ada di antara mereka yang dengan tekun membaca ayat-ayat yang tertulis di cakrawalacakrawala ciptaan Allah SWT. Salah satu di antaranya adalah pemenang hadiah Nobel pertama dari kalangan Islam, Prof. Abdus Salam yang memperoleh hadiah Nobel di bidang fisika (Mahzar, 1983, 133).

Karakter Integralistik pendidikan Islam yang dibutuhkan generasi millennial juga dapat dilakukan pada adanya integrasi pada paham Islam yang bercorak Ulum al-Din, al-Fikri dan Dirasat Islamiyah. Paham Islam Ulum al-Din yang cenderung menekankan sisi keagamaan, ritualitas, formalitas, sectarian, lokal, dangkal, parsial (sepotong-sepotong), provincial (terkotak-kotak; terbatas cara pandangnya); parochical (sempit); Sedangkan al-Fikr al-Islamiy atau Islamic Thoght yang pendekatannya lebih historis, sistematis, utuhkomprehensif, non sectarian, tidak provincial; dan Dirasat Islamiyah (Islamic Studies) yang selain masih merujuk pada kluster ilmu-ilmu keagamaan (Islam) yang patenm standar baku dalam Ulum alDin dan al-Fikr al-Islamy, ia juga ditopang dan diperkokoh oleh research (penelitian) lapangan, pematan historis-empiris yang obyektif tentang dinamika sosial, ketersambungan (continuity) dan perubahan(change), pola dan trend pergumulan sosial politk, ekonomi, budaya, pola-pola ketegangan, konflik, harmoni dan merekam pluralitas interpretasi makna oleh para pelaku di lapangan (Abdullah, 2009, 277-278).

Islam dalam paham Ulum al-Din masih berada pada tahap canonical, bahkan local dalam arti parochicaal-provincia; sedangkan al-Fikri al-Islami berada pada tahap transisi ke arah pematangaan

\section{Hasil Penelition}

munculnya Dirasaat Islamiyah yang bercorak critical, dan global. Sehubungan dengan ini, M.Amin Abdullah mengatakan:

Menurut hemat penulis, tetapi yang diperlukan untuk mengobati kecenderungan konservatisme dan eksklusifisme pendidikan agama di era modern" adalah bagaaimana mengelaas, menghubungkan dan mempertautkan hubungan yang kokoh antara ketiganya. Dirasat Islamiyah atau Islamic Studies yang bercorak critical dan dialogical perlu dikenalkan kepada anak-anak agar nilai-nilai dari keberagamaan yang autentik untuk menyangga kehidupan bersama (peaceful coexistence, al-ta'ayus al-silmi) dapat dipelihara dan dikembang-suburkan. Perbedaan visi dan misi muslim puritan dan moderat pun dapat dijembatani. Nilai fundamental keberagamaaan Islam yang bersifat altruistic (Taqdim 'ala al-ghair; al-Itsar:mendahulukan dan memprioritaskan kepentingan orang lain dan umum daripada kepentingan sendiri dan kelompok) perlu ditonjolkan kepada anak didik dan masyarakat luas, dan bukannya cuma nilai-nilai yang bersifat egoistic, agitative, dan acitivistic (Abdullah, 2009, 277-2780).

Melalui pendekatan integralisme ini, maka nilai-nilai positif yang terdapat pada Ulum al-Din, seperti berpegang teguh pada 'aqidah, kepatuhan dan ketekunan dalam menjalankan ritualitas kegamaan termasuk yang hukumnya sunnah, seperti shalat tahajjud, puasa Senin Kamis, membaca dan menghafal al-Qur'an,berzikir dan berdo'a setelah shalat, kesalihan dalam sikap, silaturahmi dan sebagainya; nilai-nilai positif yang terdapat dalam alFikri al-Islami, yakni pesan moral, dan spirit yang terdapat dalam ajaran Islam serta daya kritis dan analitis dari perspektif historis, sosiologis dan lainnya, sehingga menimbulkan kebanggaan pada Islam; serta pesan-pesan universalitas, kemanusiaan, keadilan, kedamaian, kebersaamaan dan sebagainya sebagaimana terdapat pada paham Islam Dirasat Islamiyah (Islamic Studies) yang menumbuhkan dimensi sikap menjunjung tinggi pesan-pesan kemanusiaan yang universal dapat ditumbuhkan. Dalam konteks era millennial seperti sekarang ini, cara yang ditempuh pendidikan Islam bukanlah mempertentangkan antara paham Islam model Ulum al-Din yang bercorak local, al-Fikr al-Islamy yang bercorak canonical dan critical dan Dirasat Islamiyah (Islamic Studies) yang bercorak global, dan bukan pula dengan cara memilih yang satu dan meninggalkan yang lainnya; melainkan dengan memadukan, mengkolaborasi dan mengintegrasikannya, mengingat pada masingmasing paham Islam tersebut terdapat nilai-nilai positif yang dibutuhkan generasi millennial. Generasi millennial butuh Islam Ulum al-Din dalam rangka menjaga identitas keislamannya, menjaga akidahnya, dan terbebas dari kecenderungan ke Barat-baratan dan kebebasan tanpa batas. Generasi millennial juga butuh al-Fikr al-Islamy dalam rangka menumbuhkan 
kebanggaan pada Islam dan memiliki argumentasi yang kokoh dan komprehensif atas Islam yang dianutnya. Selanjutnya generasi millennial juga butuh Dirasat Islamiyah (Islamic Studies) dalam rangka memberikan kemampuan untuk merespon berbagai problema kehidupan dari perspektif ajaran Islam, serta kemampuan membangun kerjasama dan kolaborasi dengan berbagai pandangan yang dikemukakan para ahli dalam berbagai bidang ilmu lainnya, tanpa kehilangan identitas. Dengan menggunakan pendekatan kollaboratif dan integrasi yang demikian itu, maka yang akan dihasilkan adalah manusia yang dari segi amaliyahnya seperti seorang kiai, dari segi pemikirannya seperti cendekiawan, dan dari segi kiprahnya seperti seorang peneliti, ilmuwan yang membawa pesan perdamaian pada dunia. Pendidikan Islam di era millennial harus mampu mengembang missi integrasi yang demikian itu.

\section{Pendidikan Islam dalam Menyiapkan Generasi Unggul dan Keteladanan Rasulullah SAW}

Generasi millennial sebagaimana dikemukakan di atas, adalah generasi yang harus mampu bersaing dan dalam persaingan tersebut ia harus keluar sebagai pemenang. Untuk itu, generasi millenneial adalah generasi yang unggul baik dari aspek hard skill, maupun soft skill (moral, mental, intellektual, emosional dan spiritual). Generasi yang unggul itu hanya akan dapat dilihirkan oleh pendidikan yang unggul, sebagaimaana yang diperlihatkan oleh bangsa-bangsa yang maju di dunia ini. Hasil kajian para ahli telah memperlihatkan, bahwa antara kemajuan suatu bangsa memiliki korelasi yang positif dengan keunggulan suatu bangsa; dan keunggulan suatu bangsa memiliki korelasi yang positif dengaan keunggulan pendidikan.

Pendidikan Islam dengan rujukan utamanya al-Qur'an dan al-Sunnah sesungguhnya memiliki komitmen pada keunggulan. Islam mengajarkan agar manusia memiliki sifat-sifat Allah dan Rasul-Nya. Yakni berakhlak dengan akhlak Tuhan dan Rasul sesuai kadar kesanggupan manusia (al-takhalluq bi akhlaq Allah wa al-Rasul 'ala thaawa al-basyariah). Karena Allah dan Rasul-Nya bersifat Unggul dan Maha Sempurna, maka pernyataan tersebut mengandung isyarat bahwa dalam melaksanakan pendidikan harus meniru keunggulan dan kesempurnaan sifat-sifat dan perbuatan Tuhan. Demikian pula perintah tentang iman dan amal shalih, menunjukkan bahwa pendidikan Islam selain perlu memiliki komitmen moral dan spiritual yang luhur, juga mengacu kepada standar operating prosedur (SOP) yang benar dan berdasar pada teori keilmuan yang sahih, sehingga pekerjaan tersebut dilakukan secara professional dan dapat dipertanggung jawabkan kepada publik. Waktu yang disediakan Tuhan hanya akan menimbulkan kerugian jika tidak digunakan secara produktif dalam bentuk iman dana amal shaleh. Yakni pekerjaan yang memiliki motivasi dan komitmen moral dan spiritual yang luhur, juga mengacu kepada standar operating prosedur (SOP) yang benar dan berdasar pada teori keilmuan yang sahih (Q.S. al-'Ashr, 103:1-3); Tuhan menjadikan hidup dan mati sebagai peluang untuk melakukan yang terbaik. (Q.S. al-Mulk, 67:2). Nabi Muhammad SAW sendiri telah menjadi model yang terbaik bagi manusia (laqad kaana lakum fi rasulillah uswatun hasanah). Pendidikan Islam yang unggul dalam rangka menyiapkan generasi millinneal yang unggul juga telah dicontoh oleh Nabi Muhammad SAW pada Lembaga pendidikan pertama di Madinah yang bernama Shuffah. Dengan mengambil tempat di bagian pinggir masjid Nabawiy, menunjuk Nabi Muhammad SAW sebagai guru, al-Qur'an dan Hadis sebagai inti atau pokok kurrikulum dan syllabus; infak, sedekah dan ghanimah serta lainnya sebagai sumber dana; Nabi Muhammad SAW telah berhasil melahirkan lulusan yang unggul yang selanjutnya sebagai pelopor yang membangun kebudayaan dan peradaban Islam. Di antara lulusan Shuffah yang jumlahnya sekitar 300-an, terdapat nama Abu Hurairah (ahli Hadis), Zaib bin Tsabit (ahli alQur'an), Abu Zar al-Ghifari (ahli ilmu tasawuf dan sosial), Ali bin Abi Thalib (ahli ilmu faraid dan matematika), Salman al-Farisi (ahli Irigasi dan Bendungan), Ibn Umar (ahli Fiqih/Hukum), dan sebagainya. Demikian pula melalui Lembaga pendidikan al-Kuttab, al-Badiah, al-Qushr (Istana), Rumah Ulama, Perpustakaan, Observatorium, Madrasah dan lainnya telah dilahirkan para lulusan dalam berbagai ilmu yang bertarap internasional. Abu Hanifah, Imam Malik, Imam Syafi'i dan Ahmad Ibn Hambal dalam bidang fiqih/hukum; Ibn Abbas, Ath-Thabari, dan Ibn Katsir dalam bidang Tafsir/AlQur'an; Imam Bukhari, Imam Muslim; Imam Turmudzi, Imam Nasai, Imam Ibn Majah dan Imam Abu Daud dalam bidang Hadis; Abu Hasan alAsy'ari, Imam Maturidi, Washil bin Atha dan alJubai dalam bidang teologi; Imam al-Ghazali, Zunnun al-Misri, Ibn Arabi, al-Jilli, Jalaluddin Rumi dan Abdul Qadir al-Jailani dalam bidang Tasawuf/Tariqat; al-Kindi, al-Farabi, Ibn Sina dan Ibn Rusyd dalam bidang filsafat Islam; alKhawarizmi dalam bidang matematika, al-Razi dalam bidang fisika, al-Tusi dalam bidang astronomi, Ibn Batuthah dalam bidang geology; al-Kindi, alFarabi, Ibn Sina dan Ibn Rusyd dalam bidang kedokteran/Ilmu pengetahuan murni di samping ahli filsafat; Ibn Khaldun dalam bidang sosiologi; dan sebagainya. Mereka diakui sebagai ilmuan yang unggul, karenaa mendapatkan pendidikan yang unggul. Mereka dikenal pula sebagai ilmuwan yang Ensiklopedik, all round dan multi talented, karena di samping memiliki keahlian yang merupakan keunggulannya, juga memiliki kemampuan dalam bidang lainnya. Ibn Sina misalnya selain ahli filsafat 
juga mahir dalam bidang kedokteran, ilmu jiwa, tafsir, dan tasawuf. Demikian pula Ibn Rusyd, selain ahli dalam filsafat juga ahli dalam bidang kedokteran dan hukum Islam (Harun 1979). Ajaran normative dan pengalaman sejarah yang terkait dengan pengembangan pendidikan yang unggul dan integrated yang demikian itu, patut dipraktekkan kembali dalam rangka menghasilkan generasi unggul di era millennial. Kondisi objektif pendidikan Islam saat ini nampaknya lebih banyak yang kurang siap dan kurang mampu dalam menghasilkan generasi unggul yang dibutuhkan era millennial.

\section{Perhatian Pendidikan Islam terhadap bidang Entrepreneurship}

Saat ini di Indonesia terdapat sekitar 27.000 pondok pesantren. Selain ada yang bercorak tradisional (salafiyah) yang hanya menyelengarakan pendidikan ilmu agama Islam; ada yang bercorak modern (khalafiyah) yang di samping menyelenggarakan pendidikan ilmu agama, juga menyelenggarakan pendidikan umum, mulai tingkat Taman Kanak-kanak, dasar, menengah hingga perguruan tinggi dengan berbagai bentuknya: politeknik, akademi, sekolah tinggi, institute maupun universitas. Di antara Lembaga-lembaga pendidikan Islam tersebut ada yang tergolong maju, terkemuka dan mendapat pengakuan yang luas baik nasional maupun internasional. Pondok pesantren Darussalam, Gontor Ponorogo, Jawa Tengah; Pondok Pesantren Darul Umum di Jombang, jawa Timur, Pondok Pesantren Tebu Ireng, Jombang Jawa Timur, Pondok Pesantren Tambak Beras, Pondok Pesantren Sunan Drajat, Paciran, Lamongan, Jawa Timur; dan Pondok Pesantren Modern lainnya yang baru tumbuh dan berkembang di berbagai daerah di Indonesia yang jumlahnya belum dapat diketahui dengan pasti.

Hal yang menarik dari pertumbuhan dan perkembangan pendidikan Islam termasuk yang berada di Pondok Pesantren yang tergolong modern tersebut statusnya swasta. Kemajuan, nama besar, kepercayaan masyarakat, jenis dan jenjang program pendidikan yang beragam, area kampus yang luas, infra-structure, sarana, prasarana, fasilitas yang lengkap dan modern, manajemen pengelolaan yang professional, kondisi keuangan yang sehat dan kuat, kemasan, branded dan pemasaran yang modern, mereka capai dengan usaha dan kerja keras yang tidak mengenal Lelah, serta keuletan dan keberanian dalam mengambil keputusan dengan resiko yang diperhitungkan. Adanya kemajuan yang dicapai Lembaga pendidikan Islam tersebut menujukan bahwa di dalam Lembaga pendidikan tersebut adalah kegiatan entrepreneurship (kewirausaha atau wiraswasta). Wiraswasta terdiri dari tiga kata:wira,swa dan sta, masing-masing berarti: wira adalah manusia unggul, teladan, berbudi luhur, berjiwa besar, pahlawan, pendekar kemajuan, dan memiliki keagungan watak, swa artinya sendiri; dan sta artinya berdiri. Dengan demikian secara etimologi, wiraswasta berari keberanian, keutamaan seta keperkasaan dalam memenuhi kebutuhan serta memecahkan permasalahan hidup dengan kekuatan yang ada pada diri sendiri (Alma, 2011, 17). Sumber lain menyebutkan bahwa entrepreneur diartikan: Orang yang pandai atau berbakat mengenali produk baru, menentukan cara produksi baru, menyusun operasi untuk mengadakan produk baru, memasarkannya, serta mengatur permodalan operasinya (Djatmiko, 2011, 7). Selain itu, seorang wirausaha adalah orang yang memegang prinsip integritas, kejujuran, keadilan, martabat manusia, komitmen, tanggung jawab sosial, dan kebaikan umum (Byron, 2010, 63-219).

Wirausaha berbeda dengan pedagang atau saudagar yang berasal dari kata sau yang berarti seribu, dan dagar yang artinya akal. Jadi saudagar berarti seribu akal (Rashid, 1981:4) lihat juga (Alma, 2011,17 ). Seorang pedagang terbatas pada kegiatan membeli dan menjual produk yang dibuat oleh orang lain, dengan tujuan terbatas pada mencari keuntungan. Sedangkan seorang wirausaha harus ada inisiatif, kreatifitas, menciptakan hal baru, menyediakan pekerjaan bagi orang lain, menanggung resiko, menciptakan hal-hal baru, memulai dari nol, kerja keras dan tidak kenal lelah, motivasi dan komitmen yang tinggi, jujur, keterbukaan, kreatif, kritis, produktif, dan pengambil resiko (Nugroho, 2015, 8). (Suryana, 2015, 8). Mereka yang memiliki jiwa yang demikian itu antara lain Henry Ford, Thomas Edison, Philips, Krupp, Mitsui, Sciciro Honda, Bahruddin, Pardede dan sebagainya. Di antara mereka itu ada yang berasal dari kaum bangsawan, sarjana, tetapi kebanyakan termasuk orang yang tidak tinggi sekolahnya (Alma, 2011, 17).

Dengan memperhatikan catatan tersebut di atas, dapat diketahui bahwa adanya kemajuan yang terdapat Pendidikan Islam sebagaimana yang terjadi pada Pondok Pesantren, menunjukkan bahwa Pondok Pesantren tidak hanya telah memiliki wawasan, pemahaman dan penghayatan terhadap nilai-nilai dan sikap kewirausahaan, juga telah mempraktekkan. Sikap yang dimiliki para pendiri dan pengelola Lembaga pendidikan termasuk para kiai adalah para entrepreneur yang memiliki wawasan, pemahaman, penghayatan dan pengamalan nilai-nilai kewirausahaan (inisiatif, kreatifitas, menciptakan hal baru, menyediakan pekerjaan bagi orang lain, menanggung resiko, menciptakan hal-hal baru, memulai dari nol, kerja keras dan tidak kenal lelah, motivasi dan komitmen yang tinggi, jujur, keterbukaan, kreatif, kritis, produktif, dan pengambil resiko). Sikap kewirausahaan ini sejalan dengan sikap generasi millennial sebagaimana tersebut di atas, yakni dinamis, inovatif, kreatif, dan berani keluar dari kebiasaan lama (out of the box). Dengan demikian, dapat diperkirakan, bahwa para lulusan dari Lembaga pendidikan telah memahami, 
menghayati dan mempraktekkan kewirausahaan yang sejalan dengan mental generasi millennial. Namun demikian, dalam realitanya ada pondok pesantren yang tidak mendidik secara langsung dan khusus pada lulusannya tentang kewirausahaan; dan ada pula pondok pesantren yang mengajarkan jiwa kewirausahaan yang sejalan dengan jiwa generasi millenia. Pondok Modern Gontor Ponorogo misalnya mendidik lulusannya agar memiliki jiwa keikhlasan, persaudaraan, kesederhanaan, kemandirian dan kebebasan. Jiwa ini sejalan dengan jiwa kewirausahaan dan era millennial. Demikian pula adanya pondok pesantren yang mengelola kegiatan usaha pertanian, perkebunan, peternakan, perikanan, usaha makanan dan minuma, bahkan hingga pada pembuatan kapal hingga mencapai bobot 40 ton seperti yang dilakukan Pondok Pesantren Sunan Drajat, Paciran, Lamongan, Jawa Timur, menunjukkan bahwa potensi kewirausahaan di pesantren cukup tinggi.

Dengan demikian dapat dikemukakan, bahwa pendidikan Islam akan memiliki peran yang besar dalam menyiapkan generasi yang akan siap menghadapi era millenial, apabila Lembaga pendidikan Islam tersebut ikut serta membentuk mental kewirausahaan. Hal yang demikian terjadi, karena antara nilai-nilai pendidikan kewirausahaan dengan nilai-nilai yang diperlukan bagi generasi millennial nampak saling melengkapi dan sejalan. Upaya yang harus dilakukan pendidikan Islam ini akan terasa mudah dilaksanakan, bahwa bisa dipraktekkansecara langsung, apabila memperhatikan praktek kewirausahaan yang telah dilaksanakan sebagian pondok pesantren yang tergolong maju. Tidak hanya itu, pendidikan Islam juga dapat menggali nilai-nilai kewirausahaan sebagaimana yang diajarkan oleh al-Qur'an dan telah dicontohkan pelaksanaannya oleh Rasulullah SAW.

\section{Perhatian Pendidikan Islam terhadap Manajemen Modern}

Dewasa ini sudah banyak Lembaga pendidikan Islam yang menerapkan Manajemen Modern, seperti Total Quality Management: Manajemen Mutu Terpadu (TQM) yang berorientasi pada memuaskan pelanggan dengan melakukan perbaikan secara terus menerus (continuous improvement), menentukan standar muta (quality assurance), perubahan kultur (change of culture), perubahan organisasi (upside-dowm organization), dan mempertahankan hubungan dengan pelanggan (keeping close to the customer) (Sallis, 2006, 7-11). Selain itu, banyak pula Lembaga pendidikan Islam yang menerapkan strategic manajemen yang bertumpu pada tercapanya competitive advantage (keunggulan yag berdaya saing) yang ditandai oleh adanya rumusan visi, misi, tujuan dan sasaran berdasarkan analis SWOT yakni dengan berdasarkan pada kekuatan yang dimiliki (Strengtenth),

\section{Hasil Penelition}

kelemahan yang masih dimiliki (weakness), kesempatan yang tersedia (opportunity ) dan tantangan yang dihadapi (treathmen) (Gregory G. 2003, 149-183) lihat juga (Purwanto, 2007, 73-117). Bahkan ada pula yang menerapkan SWOT Balance Scorecard yang dimodifikasi dan dikembangkan, yang semula bertumpu mengukur kemajuan dari keseimbangan yang dicapai dalam bidang keungan, pelanggan, proses produksi dan sumber daya manusia, menjadi pada prestasi lulusan, hasil akreditasi, dan sebagainya. Manajemen yang demikian adalah yang paling sesuai dan dibutuhkan masyarakat era milenial. SMU Madania, Jampang Parung, Bogor, Insan Cendekia, Serpong, Tangerang, Banten, Madrasah Pembangunan UIN Syarif Hidayatullah Jakarta, Ciputat, Tangerang Banten, MIN, MTSN, dan MIN Malang, Jawa Timur, adalah di antara Lembaga pendidikan Islam yang telah menerapkan TQM, Strategic Management dan Balanced Scorecard (Rangkuti, 2017, 1-4). Hal yang demikian terjadi, karena dari sejak awal didirikannya Lembaga-lembaga pendidikan tersebut, termasuk Institut Agama Islam Negeri (IAIN) yang kini banyak yang jadi Universitas Islam Negeri adalah agar lulusannya dapat hidup di era masayarakat modern. Natsir sebagai salah seorang tokoh pendiri Perguruan Tinggi Islam misalnya menekankan pentingnya STI menghasilkan kelompok intelektual yang memiliki basis pengetahuan keislaman dan kebudayaan yang kuat sebagai alternative pendidikan ala Barat (Jabali, 2003, 4). Demikian pula Lembagalembaga pendidikan yang berada di bawah naungan Muhammadiyah, Persatuan Islam, dan lainnya juga menghasilkan lulusan yang unggul dan modern. Pada kedua organisasi ini upaya pembaharuan pemikiran (ijtihad) mendapatkan perhatian yang sungguhsungguh, dan kesediaan untuk meninggalkan pendapat yang telah diambil dan memberi tempat kepaa pendapat orang lain yang didasarkan atas argumen yang lebih kuat (Noer, 1982, 107). Lihat juga (Nata, 2014, 279-292). Sikap seperti sangat disukai generasi era millennial.

Tidak hanya itu, Lembaga pendidikan Islam saat ini juga sudah banyak yang mengenal dan menerapkan kepemimpinan modern, seperi kepemimpinan yang berbasis budaya, manajemen berbasis sekolah, (Departemen Pendidikan Nasional, 2001, 1-65) dan manajemen berbasis emosioal (Goleman, tp. Th, 35-127). Manajemen Berbasis Kinerja (Bacal, 2005, 1-12). Yaitu dan budaya Lembaga (corporate culture) lihat juga (Moeljono, 2007) (Muhaimin, 2009, 2-7). Pendidikan Islam juga telah banyak yang menggunakan berbagai komponen pendidikan dengan paradigm baru yang didasarkan pada analisis problema yang harus dijawab di era globalisasi dan millennial, (Mastuhu, 1999, 8-19) lihat juga (Sistem Pendidikan Nasional, 2007, 9-15) seperti dalam pendekatan dan strategi pembelajaran, kurikulum, (pendekatan subjek akademis, pendekatan 
humanis, pendekatan teknologis, dan rekonstruksi sosial) (Muhaimin, 2009, 139-173). evaluasi, dan lain sebagainya.

\section{Kesimpulan}

Berdasarkan uraian dan analisa sebagaimana tersebut di atas, dapat dikemukakan catatan penutup, sebagai berikut.

1. Era millennial adalah era yang ditandai antara lain oleh lahirnya generasi yang memiliki ciriciri: (1)suka dengan kebebasan; (2)senang melakukan personalisasi; (3)mengandalkan kecepatan informasi yang instant; (4)suka belajar; (5)bekerja dengan lingkungan inovatif, (6)aktif berkolaborasi, dan (7)hyper technology (Tapscott, 2008). (8)critivcal, yakni terbiasa berfikir out of the box, kaya ide dan gagasan; (9)Confidence, yakni mereka sangat percaya diri dan berani mengungkapkan pendapat tanpa raguragu; (10)Connected, yakni merupakan generasi yang pandai bersosialisasi, terutama dalam komunitas yang mereka ikuti; (11)berselancar di social media dan internet (Farouk, 2017, 7). (12)sebagai akibat dari ketergantungan yang tinggi terhadap internet dan media sosial, mereka menjadi pribadi yang malas, tidak mendalam, tidak membumi, atau tidak bersosialisasi; (13)cenderung lemah dalam nilai-nilai kebersamaan, kegotong-royongan, kehangatan lingkungan dan kepedulian sosial; (14)cenderung bebas, kebarat-baratan dan tidak memperhatikan etik dan aturan formal, adat istiadat, serta tata krama.

2. Baik secara normative, filosofis dan historis, pendidikan Islam siap menghadapi era millennial. Yakni siap menyiapkan sumber daya manusia yang dibutuhkan di era millennial, dan sekaligus dapat mengatasi berbagai problema kehidupan yang timbul di era tersebut. Kesiapan pendidikan Islam dalam menghadapi era millennial ini, dapat dilihat pada, enam hal. Yaitu (1)Sifat dan karakteristik Pendidikan Islam; (2)perhatian pendidikan Islam terhadap perbaikan karakter yang cukup besar; (2)integralisme pendidikan Islam; (4)pendidikan Islam dalam penyiapan generasi unggul dan keteladanan Rasulullah SAW; (5) perhatian pendidikan Islam terhadap bidang entrepreneur, dan (6)perhatian pendidikan Islam pada manajemen modern.

3. Bahwa keberhasilan Rasulullah SAW dalam mendidik generasi awal pada khususnya, dan mengatasi problema umat pada umumnya adalah karena ketepatan beliau dalam memotret permasalahan problema umat serta menawarkan cara pemecahannya yang strategis, serta kemauan yang kuat untuk mewujudkannya, yang ditopang oleh akhlak mulia. Keenam hal yang ditawarkan pendidikan Islam sebagaimana tersebut di atas, diharapkan dapat menjadi strategi yang tepat guna menghadapi era millennial. Namun seberapa besar efektifitas atau keberhasilan yang dapat dicapai oleh pendidikan Islam dalam mengatasi masalah era millinneal tersebut, amat bergantung pada kemauan yang kuat dari seluruh pihak yang berkeimpun dalam bidang pendidikanu ntuk mewujudkannya, yang ditopang oleh akhlak mulia, serta hidayah Allah SWT. Wallahu a'lam bis shawaab.

\section{Daftar Pustaka}

Abdurrahman, Moeslim, (1997). Islam Transformatif, Jakarta:Pustaka Firdaus. cet. III.

Al-Abrasyi, Mohd. Athiyah, (1974). Dasar-dasar Pokok Pendidika Islam, (terj.) Bustami A. Gani dan Djohar Bahry L.I.S., dari judul asli, al-Tarbiyah al-Islamiyah, Jakarta:Bulan Bintang. cet. II.

Al-Ahwany, Ahmad Fu'ad, al-Tarbiyah fi al-Islam, (Mesir: Dar al-Ma'arif, tp.th.).

Azra, Ayumardi, (1996). Islam in the Indonesian World An Account of Institutional Formation, Bandung:Mizan Pustaka.

Alma, Buchari, (2011). Kewirausahaan untuk Mahasiswa dan Umum, Bandung:Alfabeta, XVII.

Al-Baaqy, Abd., Muhammad Fuad, al-Mu'jam alMufahras li Alfaadz al-Qur'an al-Karim, Beirut: Dar al-Fikr, 1407H./1978 M.

Bacal, Robert, (2005). Performance Manajemen, Memberdayakan Karyawan, Kinerja melalui Umpan Balik Mengukur Kinerja, Jakarta:Gramedia Pustaka Utama, cet. III.

Budi Djatmiko, Muhammad, (2011). Entrepreneurship Go International, Cara Mudah dan Benar Menjadi Pengusaha, Bandung:STEMBI Bandung Business School, cet. III.

Buchori, Mochtar, (1994). Pendidikan dalam Pembangunan, Jakarta:IKIM Muhammadiyah Jakarta Press, cet. I. , (2005). Pendidikan Antisipatoris, YogyakartaLKanisius, cet. V.

Byron, William J., (2010). The Power of Principles Etika untuk Budaya Baru Perusahaan, Yogyakarta:Kanisius.

Departemen Pendidikan Nasional, (2001). Manajemen Peningkatan Mutu Berbasis Sekolah, Jakarta:Diirektorat Jenderal Pendidikan Dasar dan Menengah Direktorat Pendidikan Menengah Umum, Departemen Pendidikan Nasional. 


\section{Haril Penelition}

Al-Djamali, Fadhil, (1920). Menerabas Krisis Pendidikan Dunia Islam, Jakarta:Golden Trayon, cet.II

Jabali, Fu'ad, dan Jamhari, (2003). IAIN \& Modernisasi Islam di Indonesia, Jakarta:UIN Jakarta Press, 1424 H./2003 M. cet.I.

O’Neil, William F., (2008). Ideologi-ideologi Pendidikan, (alih bahasa:Omi Intan Naomi) dari judul asli Educational Ideologies Contemporary Expressions of Educational Philosophoes, Yogyakarta:Pustaka Pelajar, cet. I.

Fuller, Graham E., (2010). A Wordl Without Islam, New York, Boston dan London:Little Brown and Company.

Gregory, dan G.T. Lumpkin, (2003). Strategic Management Creating Competitive Advantage, New York, London:McGrawHill, Irwin.

Hidayatullah, Taufik, Islam dan Pendidikan Karakter Paradigma Pendidikan Living Values Education (Studi Kasus di Sekolah Madania, (Jakarta:Sekolah Pascasarjana Universitas Islam Negeri (UIN) Syarif Hidayatullah Jakarta.

Ismail, Saminan, (2013). Budaya Sekolah Islam, Bandung:Rizqi Press, cet. I.

Al-Kailany, Majid Irsan, al-Fikry al-Tarbawiy ind Ibn Taimiyah, Madinah al-Munawwarh: Maktabah Dar al-Turats, tp. Th..

Langgulung, (1986), Manusia dan Pendidikan suatu Analisa Psikologi dan Pendidikan, Jakarta:Pustaka Alhusna, cet. I.

Lickona, Thomas, (2012), Character Matters Persoalan Karakter Bagaimana Membantu Anak Mengembangkan Penilaian yang Baik, Integritas, dan Kebajikan Penting Lainnya, Jakarta:Bumi Aksara, cet. I.

Al-Maraghy. Ahmad Mushthafa, Tafsir al-Maraghy, al-Mujallid I, Beirut: Dar al-Fikr, tp. Th.

Mastuhu, (2007), Sistem Pendidikan Nasional, Ciputat:Lentera Hati, cet. I.

(1999), Memberdayakan Sistem Pendidikan Islam, Jakarta:Logos Wacana Ilmu, cet. II.

Al-Mawardy, Abi al-Hasan Ali bin Muhammad bin Jaib al-Bashry, Adab al-Dun-ya wa al-Din, Beirut: Dar al-Fikry, tp.th.

Moeljono, Djokosantoso dan Steve Sudjatmiko, (ed.), (2007), Corporate Culture:Challenge to Excellence, Jakarta:PT Elex Media Komputindo Kelompok Kompas-Gramedia, cet. I.

Muhaimin, (2009). Pengembangan Kurikulum Agama Islam di Sekolah, Madrasah dan Perguruan Tinggi, Jakarta:Raja Grafindo Persada.

Muhaimin, dkk, (2010). Manajemen Pendidikan Aplikasinya dalam Penyusunan Rencana
Pengembangan

Sekolah/Madrasah,

Jakarta:Prenada Media Group, cet.II.

, (2006). Nuansa Baru Pendidikan Islam Mengurai Benang Kusut Dunia Pendidikan, Jakarta:Raja Grafindo Persada,

Nata, Abuddin, (2014). Sosiologi Pendidikan Islam, (Jakarta: RajaGrafindo Persada, cet. I.

, (2015). Akhlak Tasawuf dan Karakter Mulia, Jakarta:RajaGrafindo Persada, cet. XIV.

Noer, Deliar, (1982). Gerakan Modern Islam di Indonesia 1900-1942, Jakarta:LP3ES,

Nucci, Larry P, dan Darcia Narvaes, Hand book, Pendidikan Moral dan Karakter Handbook of Moral and Character Education, (Bandung:Nusa Media, 2015), cet. II.

Nugroho, Riant, (2015). Membangun Entrepreneur Indonesia Tantangan Manajemen Pemerintahan Jokowi, (Jakarta:Kompas Gramedia.

Nurfuadi, (2012). Profesionalisme Guru, Purwokerto:STAIN Press, Purwokerto.

Poeradisastra, S.I.Sumbangan Islam kepada Ilmu \& Peradaban Modern, (Jakarta:LP3M, 1986), cet. II

Purwanto, Iwan, (2007). Manajemen Strategi, Bandung:Yrama Widya, cet. I.

Rangkuti, Freddy, SWOT Balance Scorecard, (2017). Teknik Menyusun Strategi Korporat yang Efektif plus Cara Mengelola Kinerja dan Risiko, Jakarta:PT Gramedia Pustaka Utama, cet. XI.

Rozak Abd. (2010). Pengembangan Profesi Guru, Jakarta:Fakultas Ilmu Tarbiyah dan Keguruan (FITK) UIN Syarif Hidayatullah Jakarta, Cet. I.

Sallis, Edward, (2006). Total Quality Management in Education, Manajemen Mutu Pendidikan, Jogjakarta:IRCiSoD, cet. I.

Al-Sarjani, Raghib, Sumbangan Islam pada Dunia, (Jakarta:Pustaka al-Kautsar, 2011), cet. I.

Saridjo, Marwan, (ed.), (2009). Mereka Bicara Pendidikan Islam sebuah Bunga Rampai, Jakarta:RajaGrafindo Persada, cet. I.

Soetjipto dan Raflis Kosasi, (2009). Profesi Keguruan, Jakarta:Rineka Cipta dan Pusat Perbukuan Depdiknas.

Sudaryono, (2014). Perilaku Konsunen dalam Perspektif Pemasaran, Jakarta:Lentera Ilmu Cendekia, cet. I.

Suryana, Yuyus, dan Kartib Bayu, (2010). Kewirausahaan Pendekatan Karakteristik Wirausahawan Sukses, (Jakarta:Prenadamedia Group, cet. I.

Syafruddin, (2010). Kepemimpinan Pendidikan Akuntabilitas Pimpinan Pendidikan dalam Konteks Otonomi Daerah, Ciputat:Quantum Teaching. 
Tjahjono, Herry, (2011). Culture Based Leadership Menuju Kebesaran Diri \& Organisasi melalui Kepemimpinan Berbasis Budaya dan Budaya Kinerja Tinggi, Jakarta:Kompas Gramedia, cet. I.

Toffler, Alvin, Author of Future Shock, (1980). The Third Wave, New York:William Morrow and Company, Inc.

Welsh, Frank, (2011). The History of the World from the Dawn of Humanity to the Modern Age, London:Quercus, cet. I.

Zenger, John H., Joseph R. Folman, et all, (2013). Ho to Be Exceptional Mendorong Kesuksesan Kepemimpinan dengan Melipatgandakan Kekuatan, Jakarta:Gramedia.

Zubaidi, (2011). Desain Pendidikan Karakter Konsepsi dan Aplikasinya dalam Lembaga Pendidikan, Jakarta:Prenada Media, ce. I. 